\title{
Innate Immunity Provides Biomarkers of Health for Teleosts Exposed to Nanoparticles
}

\author{
Débora Torrealba ${ }^{1,2}$, Juan A. More-Bayona ${ }^{1}$, Jeremy Wakaruk ${ }^{2}$ and Daniel R. Barreda ${ }^{1,2 \star}$ \\ ${ }^{1}$ Immunology and Animal Health Laboratory, Department of Biological Sciences, University of Alberta, Edmonton, AB, \\ Canada, ${ }^{2}$ Department of Agricultural, Food and Nutritional Science, University of Alberta, Edmonton, AB, Canada
}

In recent years, the unique properties of nanoparticles have fostered novel applications in various fields such as biology, pharmaceuticals, agriculture, and others. Unfortunately, their rapid integration into daily life has also led to environmental concerns due to uncontrolled release of nanoparticles into the aquatic environment. Despite increasing awareness of nanoparticle bioaccumulation in the aquatic environment, much remains to be learned about their impact on aquatic organisms and how to best monitor these effects. Herein, we provide the first review of innate immunity as an emerging tool

OPEN ACCESS

Edited by:

Eva-Stina Isabella Edholm, UiT The Arctic University of Norway,

Norway

Reviewed by

Annalisa Pinsino,

Istituto di Biomedicina e di Immunologia Molecolare Alberto

Monroy (IBIM), Italy

Sylvia Brugman,

Wageningen University \& Research,

Netherlands

*Correspondence:

Daniel R. Barreda

d.barreda@ualberta.ca

Specialty section:

This article was submitted to

Comparative Immunology,

a section of the journal

Frontiers in Immunology

Received: 14 September 2018 Accepted: 12 December 2018

Published: 09 January 2019

Citation:

Torrealba D, More-Bayona JA Wakaruk J and Barreda DR (2019) Innate Immunity Provides Biomarkers

of Health for Teleosts Exposed to

Nanoparticles.

Front. Immunol. 9:3074.

doi: 10.3389/fimmu.2018.03074 to assess the health of fish following nanoparticle exposure. Fish are widely used as sentinels for aquatic ecosystem pollution and innate immune parameters offer sensitive and reliable tools that can be harnessed for evaluation of contamination events. The most frequent biomarkers highlighted in literature to date include, but are not limited to, parameters associated with leukocyte dynamics, oxidative stress, and cytokine production. Taken together, innate immunity offers finite and sensitive biomarkers for assessment of the impact of nanoparticles on fish health.

Keywords: innate immunity system, nanoparticles, teleosts, oxidative stress, leukocytes

\section{INTRODUCTION}

Nanoparticles (NPs) are an emerging technology, currently being applied in various fields including medicine, cosmetics, electronics, space science, chemical manufacturing, cellular and molecular biology, agricultural and animal science (1-4). Nanomaterials are structures of $1-1,000 \mathrm{~nm}$ in size; however, stricter definitions restrict them to those in the $1-100 \mathrm{~nm}$ range (National Nanotechnology Initiative). NPs have been developed in many different inorganic and organic forms but most current NPs are classified into four material-based categories: (i) carbon based NPs such as fullerenes and carbon nanotubes; (ii) inorganic-based NPs including metal (e.g., gold NPs, silver NPs) and metal oxide NPs (e.g., titanium dioxide NPs, zinc oxide NPs); (iii) organicbased NPs such as dendrimers, liposomes, polymers; and (iv) composite-based NPs: combinations of different material-based NPs $(1,2)$.

The rising use of NPs in modern technologies has led to unregulated release and accumulation into the aquatic environment, contributing to further pollution $(5,6)$. For example, aquatic release of titanium dioxide $\mathrm{NP}\left(\mathrm{TiO}_{2}\right)$ has been estimated at $17 \%$ of their total production per year (7). Based on a production scale of $88 \mathrm{kt} / \mathrm{year}$, this translates into a significant aquatic release of $15.6 \mathrm{kt} / \mathrm{year}$. Releases for other nanomaterials have been recently summarized (7). NPs enter the aquatic environment mainly through wastewater and effluents from industrial sources, as well as via atmospheric deposition, leaching from soil, accidental spillages, and agricultural drainage water $(1,5)$. Naturally-occurring NPs also enter aquatic 
environments through waterways across several landscapes (8). Despite our growing knowledge about NP bioaccumulation within aquatic environments, little is known about the detrimental effects of nanoparticles on animal and human health. Various features such as size, chemical makeup, biodegradability, and the physicochemical environment all affect the extent to which NPs are contributors of biotoxicity $(5,9)$.

Fish are widely used as sentinels for aquatic ecosystem pollution stemming from chemical exposure and are the preferred model for development of chemical testing guidelines $(10,11)$. Among others, their practical relevance are based on: (i) wide distribution in aquatic environments; (ii) high ecological relevance due to position within food web structure, nutrient cycling and energy transfer; and (iii) expanding models and tools that researchers can use (12). In addition, testing on native species under natural housing conditions (e.g., Oncorhynchus mykiss to test freshwater pollution and aquatic toxicity in Canadian cool waters) adds relevance to these datasets (13). Consequently, fish species have now become a preferred model to study NP toxicity (14-16). A summary for recent applications of innate immune parameters as biomarkers of impact on animal health is provided in Tables $\mathbf{1}, \mathbf{2}$.

A biomarker can be any measurable biological response that reproducibly changes upon exposure to environmental pollutants (108). Recently, innate immunity has yielded a wide set of biomarkers for immunotoxicity against multiple xenobiotics including metal ions, pesticides, oil products, and chlorinated hydrocarbons (4, 9, 109-111). Among the most commonly used we find: leukocytes dynamics, phagocytic activity, lysozyme production, production of antimicrobial peptides, cytokines expression, and reactive oxygen species (ROS) production (110). Multiple studies have shown that innate immune parameters display high sensitivity to NPs. The conservation of innate parameters across animal models further makes them amenable for complementary studies, for instance, when toxicity to aquatic, and terrestrial ecosystems is of interest. Finally, early kinetics of innate parameters induction coupled to their sensitivity to capture additive or synergistic effects from environmental contaminants makes them a powerful alternative to evaluate ecotoxicity. In this review, we have drawn on recent literature to highlight those innate immunity biomarkers most often used in the assessment of teleost fish health exposed to NPs.

\section{EXTERNAL BARRIERS}

External barriers to microbes infecting fish encompass mucous secretion produced in multiple tissues such as gills, skin, and intestine. These surfaces constitute physical barriers supported by immunologically-active agents such as lysozyme, complement, lectins, proteolytic enzymes, antimicrobial peptides, and reactive chemical species (112-116). While some of these defense molecules have been used as biomarkers in fish ecotoxicology (117), just a small proportion of these have been applied to the assessment of fish health after NPs exposure. Here, we discuss their use to date and how researchers can take advantage of them to assess NP toxicity.
TABLE 1 | Innate immune defenses used as biomarkers to assess fish health post exposure to nanoparticles.

\begin{tabular}{|c|c|c|}
\hline $\begin{array}{l}\text { Innate immune } \\
\text { defenses }\end{array}$ & Nanoparticles & References \\
\hline \multicolumn{3}{|c|}{ EXTERNAL BARRIERS } \\
\hline \multicolumn{3}{|l|}{ Mucus } \\
\hline & Gold (Au) & (17) \\
\hline & Silver (Ag) & (18) \\
\hline \multicolumn{3}{|l|}{ Gills } \\
\hline & Aluminum oxide $\left(\mathrm{Al}_{2} \mathrm{O}_{3}\right)$ & (19) \\
\hline & Copper (Cu) & $(20,21)$ \\
\hline & Copper oxide (CuO) & $(22-24)$ \\
\hline & Graphene oxide (GO) & (25) \\
\hline & Gold (Au) & (26) \\
\hline & Iron oxide $\left(\mathrm{Fe}_{2} \mathrm{O}_{3}\right)$ & (27) \\
\hline & $\begin{array}{l}\text { Multi walled carbon nanotubes } \\
\text { (MWCNTs) }\end{array}$ & (28) \\
\hline & Silica coated iron oxide $\left(\mathrm{Fe}_{3} \mathrm{O}_{4}-\mathrm{SiO}_{2}\right)$ & (29) \\
\hline & Silver (Ag) & $(21,30-36)$ \\
\hline & Silver nitrate $\left(\mathrm{AgNO}_{3}\right)$ & (34) \\
\hline & $\begin{array}{l}\text { Single wallet carbon nanotubes } \\
\text { (SWCNTs) }\end{array}$ & $(37,38)$ \\
\hline & Titanium dioxide $\left(\mathrm{TiO}_{2}\right)$ & (39) \\
\hline & Zinc oxide (ZnO) & $(19,40,41)$ \\
\hline
\end{tabular}

\section{CELLULAR RESPONSE}

Leukocytes

Neutrophils

$\begin{array}{ll}\text { Cerium oxide }\left(\mathrm{CeO}_{2}\right) & (42) \\ \text { Copper }(\mathrm{Cu}) & (43) \\ \text { Gold }(\mathrm{Au}) & (43) \\ \text { Hydroxylated fullerenes }\left(\mathrm{C}_{60}(\mathrm{OH})_{24}\right) & (44) \\ \text { Iron oxide }\left(\mathrm{Fe}_{2} \mathrm{O}_{3}\right) & (42) \\ \text { Polycarbonate } & (45) \\ \text { Polystyrene } & (45) \\ \text { Silica (Si) } & (46,47) \\ \text { Silver }(\mathrm{Ag}) & (43) \\ \text { Titanium dioxide }\left(\mathrm{TiO}_{2}\right) & (42,48) \\ \text { Zinc oxide }(\mathrm{ZnO}) & (42)\end{array}$

Macrophages

Hydroxylated fullerenes $\left(\mathrm{C}_{60}(\mathrm{OH})_{24}\right) \quad(44)$ Iron oxide $\left(\mathrm{Fe}_{2} \mathrm{O}_{3}\right)$

Silica (Si) (50)

Titanium dioxide $\left(\mathrm{TiO}_{2}\right)$

Lymphocytes

Cadmium sulfate quantum dots (CdSQDs)

Cadmiun telluride quantum dots (51) (Cd-TeQDs)

Copper (Cu)

Copper oxide (CuO)

Gold (Au)

Hydroxylated fullerenes $\left(\mathrm{C}_{60}(\mathrm{OH})_{24}\right)$

Silver (Ag)

Titanium dioxide $\left(\mathrm{TiO}_{2}\right)$

(51)

(44)

(43)

$(48,53)$ 
TABLE 1 | Continued

\begin{tabular}{|c|c|c|}
\hline $\begin{array}{l}\text { Innate immune } \\
\text { defenses }\end{array}$ & Nanoparticles & References \\
\hline \multicolumn{3}{|c|}{ Internalization of nanoparticles } \\
\hline & $\begin{array}{l}\text { Cadmium sulfate quantum dots } \\
\text { (CdSQDs) }\end{array}$ & $(51,54)$ \\
\hline & $\begin{array}{l}\text { Cadmiun telluride quantum dots } \\
\text { (Cd-TeQDs) }\end{array}$ & $(51,54,55)$ \\
\hline & Copper (Cu) & (43) \\
\hline & Cobalt ferrite $\left(\mathrm{CoFe}_{2} \mathrm{O}_{4}\right)$ & $(56)$ \\
\hline & Gold (Au) & $(43,57)$ \\
\hline & Poly (acrylic acid) & (58) \\
\hline & Polycarbonate & (45) \\
\hline & Polystyrene & $(45,57)$ \\
\hline & Poly (lactic-co-glycolic acid) (PLGA) & $(57)$ \\
\hline & Silica coated iron oxide $\left(\mathrm{Fe}_{3} \mathrm{O}_{4}-\mathrm{SiO}_{2}\right)$ & $(29,59)$ \\
\hline & Silver (Ag) & $(43,60,61)$ \\
\hline & Titanium dioxide $\left(\mathrm{TiO}_{2}\right)$ & $(62,63)$ \\
\hline & Zinc oxide $(\mathrm{ZnO})$ & $(40)$ \\
\hline \multicolumn{3}{|c|}{$\begin{array}{l}\text { OXIDATIVE STRESS } \\
\text { ROS }\end{array}$} \\
\hline & Cerium oxide $\left(\mathrm{CeO}_{2}\right)$ & (42) \\
\hline & Cobalt ferrite $\left(\mathrm{CoFe}_{2} \mathrm{O}_{4}\right)$ & (56) \\
\hline & Cobalt oxide $\left(\mathrm{CO}_{3} \mathrm{O}_{4}\right)$ & $(64)$ \\
\hline & Copper (Cu) & $(43,65)$ \\
\hline & Copper oxide (CuO) & $(22,64,66,67)$ \\
\hline & Copper sulfate $\left(\mathrm{CuSO}_{4}\right)$ & (65) \\
\hline & Fullerene $\mathrm{C}_{60}$ & (68) \\
\hline & Graphene oxide (GO) & (25) \\
\hline & Gold (Au) & $(43,69)$ \\
\hline & Hydroxylated fullerenes $\left(\mathrm{C}_{60}(\mathrm{OH})_{24}\right)$ & $(44)$ \\
\hline & Iron oxide $\left(\mathrm{Fe}_{3} \mathrm{O}_{4}\right)$ & (70) \\
\hline & Iron oxide $\left(\mathrm{Fe}_{2} \mathrm{O}_{3}\right)$ & $(27,42)$ \\
\hline & Polyamidoamine (PAMAM) & $(71)$ \\
\hline & Polycarbonate & (45) \\
\hline & Polystyrene & (45) \\
\hline & Silica (Si) & $(46,47)$ \\
\hline & Silica coated iron oxide $\left(\mathrm{Fe}_{3} \mathrm{O}_{4}-\mathrm{SiO}_{2}\right)$ & $(29)$ \\
\hline & Silver (Ag) & $(43,60,72)$ \\
\hline & $\begin{array}{l}\text { Single wallet carbon nanotubes } \\
\text { (SWCNTs) }\end{array}$ & $(37)$ \\
\hline & Titanium dioxide $\left(\mathrm{TiO}_{2}\right)$ & $(39,42,48,64)$ \\
\hline & Zinc oxide $(\mathrm{ZnO})$ & $(40-42,64,73,74)$ \\
\hline \multicolumn{3}{|c|}{ Nitric oxide (NO) } \\
\hline & Cerium oxide $\left(\mathrm{CeO}_{2}\right)$ & $(75)$ \\
\hline & Copper oxide (CuO) & $(66,75)$ \\
\hline
\end{tabular}

\section{ANTIOXIDANT DEFENSES}

Superoxide dismutase (SOD)

$\begin{array}{ll}\text { Aluminum oxide }\left(\mathrm{Al}_{2} \mathrm{O}_{3}\right) & (19,76) \\ \text { Copper }(\mathrm{Cu}) & (65,77) \\ \text { Copper oxide }(\mathrm{CuO}) & (22,66,67) \\ \text { Copper sulfate }\left(\mathrm{CuSO}_{4}\right) & (65,77) \\ \text { CulnS2/ZnS quantum dots (QDs) } & (78)\end{array}$

TABLE 1 | Continued

\begin{tabular}{|c|c|c|}
\hline $\begin{array}{l}\text { Innate immune } \\
\text { defenses }\end{array}$ & Nanoparticles & References \\
\hline & Gold (Au) & $(79-81)$ \\
\hline & Iron oxide $\left(\mathrm{Fe}_{3} \mathrm{O}_{4}\right)$ & (70) \\
\hline & Silver (Ag) & $(30,34,35,72,82)$ \\
\hline & Silver nitrate $\left(\mathrm{AgNO}_{3}\right)$ & (34) \\
\hline & $\begin{array}{l}\text { Single wallet carbon nanotubes } \\
\text { (SWCNTs) }\end{array}$ & (37) \\
\hline & Titanium dioxide $\left(\mathrm{TiO}_{2}\right)$ & $(39,83)$ \\
\hline & Zinc oxide $(\mathrm{ZnO})$ & $(19,41,73,74)$ \\
\hline \multicolumn{3}{|l|}{ Catalase (CAT) } \\
\hline & Aluminum oxide $\left(\mathrm{Al}_{2} \mathrm{O}_{3}\right)$ & $(19,76)$ \\
\hline & Cobalt ferrite $\left(\mathrm{CoFe}_{2} \mathrm{O}_{4}\right)$ & (56) \\
\hline & Copper (Cu) & $(65,77)$ \\
\hline & Copper oxide (CuO) & $(22,66,67)$ \\
\hline & Copper sulfate $\left(\mathrm{CuSO}_{4}\right)$ & $(65,77)$ \\
\hline & Gold (Au) & $(80,81)$ \\
\hline & Iron (Fe) & (84) \\
\hline & Iron oxide $\left(\mathrm{Fe}_{3} \mathrm{O}_{4}\right)$ & (70) \\
\hline & Silica coated iron oxide $\left(\mathrm{Fe}_{3} \mathrm{O}_{4}-\mathrm{SiO}_{2}\right)$ & (59) \\
\hline & Silver (Ag) & $(30,35,82)$ \\
\hline & $\begin{array}{l}\text { Single wallet carbon nanotubes } \\
\text { (SWCNTs) }\end{array}$ & (37) \\
\hline & Titanium dioxide $\left(\mathrm{TiO}_{2}\right)$ & $(39,83)$ \\
\hline & Zinc oxide $(\mathrm{ZnO})$ & $(19,41,73,74)$ \\
\hline \multicolumn{3}{|c|}{ Glutathione peroxidase (GPx) } \\
\hline & Copper oxide (CuO) & $(66,67)$ \\
\hline & Gold (Au) & $(80,81)$ \\
\hline & Silica coated iron oxide $\left(\mathrm{Fe}_{3} \mathrm{O}_{4}-\mathrm{SiO}_{2}\right)$ & (59) \\
\hline & Silver (Ag) & (35) \\
\hline & Titanium dioxide $\left(\mathrm{TiO}_{2}\right)$ & (39) \\
\hline & Zinc Oxide (ZnO) & (73) \\
\hline \multicolumn{3}{|c|}{ Glutathione sulfotranferase (GST) } \\
\hline & Aluminum oxide $\left(\mathrm{Al}_{2} \mathrm{O}_{3}\right)$ & $(19,76)$ \\
\hline & Cobalt ferrite $\left(\mathrm{CoFe}_{2} \mathrm{O}_{4}\right)$ & (56) \\
\hline & Copper oxide (CuO) & $(22,67)$ \\
\hline & Fullerene $\mathrm{C}_{60}$ & (68) \\
\hline & Gold (Au) & $(80,81)$ \\
\hline & Iron oxide $\left(\mathrm{Fe}_{3} \mathrm{O}_{4}\right)$ & (70) \\
\hline & Silica coated iron oxide $\left(\mathrm{Fe}_{3} \mathrm{O}_{4}-\mathrm{SiO}_{2}\right)$ & (59) \\
\hline & Silver (Ag) & $(34,82)$ \\
\hline & Silver nitrate $\left(\mathrm{AgNO}_{3}\right)$ & (34) \\
\hline & Titanium dioxide $\left(\mathrm{TiO}_{2}\right)$ & (39) \\
\hline & Zinc oxide $(\mathrm{ZnO})$ & $(19,41)$ \\
\hline \multicolumn{3}{|l|}{ Glutathione (GSH) } \\
\hline & Aluminum oxide $\left(\mathrm{Al}_{2} \mathrm{O}_{3}\right)$ & (76) \\
\hline & Copper (Cu) & $(65,77)$ \\
\hline & Copper oxide (CuO) & (67) \\
\hline & Copper sulfate $\left(\mathrm{CuSO}_{4}\right)$ & $(65,77)$ \\
\hline & Fullerenes $\mathrm{C}_{60}$ & (85) \\
\hline & Gold (Au) & (81) \\
\hline & Silver (Ag) & (72) \\
\hline & Titanium dioxide $\left(\mathrm{TiO}_{2}\right)$ & $(39,83)$ \\
\hline
\end{tabular}

(Continued) 
TABLE 1 | Continued

\begin{tabular}{ll}
\hline $\begin{array}{l}\text { Innate immune } \\
\text { defenses }\end{array}$ & References \\
\hline
\end{tabular}

Glutathione reductase (GR)

Gold (Au)

(17)

Iron oxide $\left(\mathrm{Fe}_{3} \mathrm{O}_{4}\right)$

(70)

Silica coated iron oxide $\left(\mathrm{Fe}_{3} \mathrm{O}_{4}-\mathrm{SiO}_{2}\right)$

(59)

Oxidized glutathione (GSSG)

Copper oxide (CuO)

(67)

BIOMARKERS OF OXIDATIVE STRESS

Malondialdehyde (MDA)

Cobalt ferrite $\left(\mathrm{CoFe}_{2} \mathrm{O}_{4}\right)$
Copper $(\mathrm{Cu})$
Copper oxide $(\mathrm{CuO})$
Copper sulfate $\left(\mathrm{CuSO} \mathrm{S}_{4}\right)$
CulnS2 quantum dots (QDs)
Silver $(\mathrm{Ag})$
Titanium dioxide $\left(\mathrm{TiO}_{2}\right)$
Zinc oxide $(\mathrm{ZnO})$
Zns quantum dots $(\mathrm{QDs})$

(56)

$(65,77)$

(24)

$(65,77)$

(78)

(72)

(86)

$(41,73,74)$

(78)

Lipid peroxidation (LPO)

Aluminum oxide $\left(\mathrm{Al}_{2} \mathrm{O}_{3}\right)$

$(19,83)$

Cobalt ferrite $\left(\mathrm{CoFe}_{2} \mathrm{O}_{4}\right)$

(56)

Copper oxide (CuO)

Fullerenes $\mathrm{C}_{60}$

$(22,66,67)$

(85)

Silica coated iron oxide $\left(\mathrm{Fe}_{3} \mathrm{O}_{4}-\mathrm{SiO}_{2}\right)$

Silver (Ag)

Silver nitrate $\left(\mathrm{AgNO}_{3}\right)$

Single wallet carbon nanotubes

(SWCNTS)

Titanium dioxide $\left(\mathrm{TiO}_{2}\right)$

Zinc oxide $(\mathrm{ZnO})$

Myeloperoxidase activity (MPO)

Iron oxide $\left(\mathrm{Fe}_{2} \mathrm{O}_{3}\right)$

Zinc oxide $(\mathrm{ZnO})$

Protein carbonyl (PC)

Copper oxide (CuO)

Cytokines

Carbon Nanotubes (CNTs)

Cerium oxide $\left(\mathrm{CeO}_{2}\right)$

Copper (Cu)

Copper sulfate $\left(\mathrm{CuSO}_{4}\right)$

Gold (Au)

Hydroxylated fullerenes $\left(\mathrm{C}_{60}(\mathrm{OH})_{24}\right)$

Iron oxide $\left(\mathrm{Fe}_{2} \mathrm{O}_{3}\right)$

Silver $(\mathrm{Ag})$

Titanium dioxide $\left(\mathrm{TiO}_{2}\right)$

Zinc oxide $(\mathrm{ZnO})$

Lysozyme

\section{Mucus}

The amount and biochemical content of mucus have been used as biomarkers for the evaluation of teleost fish health exposed to NPs. Mucus on the fish skin is a first line of defense, forming a barrier protecting tissues from the surrounding environment. This barrier is secreted by goblet cells and composed mainly of water, mucopolysaccharides, mucoproteins, and other soluble materials (114). Mucus, as part of the innate immune system, plays an essential role in protecting fish from xenobiotic exposure $(114,118)$. When fish health is compromised, the mucosal matrix may also be affected. Therefore, it can be a useful tool to assess the effect of NPs in fish. Nevertheless, only two studies have evaluated skin mucus after exposure to NPs (Table 1). In the first study, Oliveira et al. presented a non-invasive method to assess the effects of gold NPs (Au) in Sparus aurata by analyzing skin mucus (17). Measurements of total antioxidant capacity and esterase activity showed the sensitivity of skin mucus exposed to NPs, even at low concentrations (17). The second study in Pimephales promelas showed an increase in mucus production between 4 and $24 \mathrm{~h}$ after exposure to silver nitrate $\mathrm{NPs}\left(\mathrm{AgNO}_{3}\right)(18)$. By day 3 , fish had considerably reduced their ability to produce mucus (18). The lack of additional studies employing mucus might be related to the limited knowledge concerning the repertoire of immune factors present in skin mucus and their precise protective role to study fish health fitness (118). Additionally, there is an inherent complexity in obtaining enough amount of mucus to analyze. Other potential biomarkers in mucus skin could be the quantification of activity of well-characterized enzymes such as protease and lysozyme (119). These prospective biomarkers may contribute to assess fish responses against a pathogen after NPs exposure. In addition, other immune-related parameters such as mucosal IgT secretion levels and the capacity for development of mucosal memory will allow the evaluation of fish health following NP exposure. These non-invasive biomarkers can be meaningful to study the fish health fitness while avoiding fish slaughter, thus, reducing the number of individuals used in environment pollution monitoring. Nevertheless, more studies are needed to define whether these parameters of skin mucus maintain consistent results in multiple experimental conditions such as NP type, concentration and exposure time.

\section{Gills}

In fish, gills are the main organs for gas exchange and have a relevant role in ionic and osmoregulatory function (120). Moreover, gills are considered to be the most sensitive organ to a majority of xenobiotics because, like the mucus on the skin, gills are in direct contact with the environment (121). However, that may not apply to NPs. In gills, evaluation of NPs effects have been performed mainly by histopathology (19$23,25,28,30-33,39,40)$, NP bioaccumulation $(21,23,24,27$, $32,34,37,39)$ and measurement of oxidative stress biomarkers $(19,22,24,25,29,30,34,35,37,39,41)$ (refer to Oxidative stress section and Table 1). Regarding histopathology, some inaccurate histopathology-based results have been published due to the high degree of expertise necessary (122). For instance, controversial results have been published regarding the effects of silver NPs (Ag) in Danio rerio. Some studies report histopathological lesions 
TABLE 2 | Species used in the evaluation of nanoparticles' effect on fish health.

\begin{tabular}{|c|c|c|}
\hline Species & Nanoparticles & References \\
\hline \multicolumn{3}{|c|}{ Apistogramma agassizii } \\
\hline & Copper oxide (CuO) & (22) \\
\hline \multicolumn{3}{|c|}{ Anguilla anguilla } \\
\hline & Silica coated iron oxide $\left(\mathrm{Fe}_{3} \mathrm{O}_{4}-\mathrm{SiO}_{2}\right)$ & $(29,59)$ \\
\hline \multicolumn{3}{|c|}{ Carassius auratus } \\
\hline & Aluminum oxide $\left(\mathrm{Al}_{2} \mathrm{O}_{3}\right)$ & (19) \\
\hline & Cerium oxide $\left(\mathrm{CeO}_{2}\right)$ & (42) \\
\hline & Iron oxide $\left(\mathrm{Fe}_{2} \mathrm{O}_{3}\right)$ & (42) \\
\hline & Titanium dioxide $\left(\mathrm{TiO}_{2}\right)$ & (42) \\
\hline & Zinc oxide (ZnO) & $(19,42)$ \\
\hline \multicolumn{3}{|c|}{ Catla catla } \\
\hline & Zinc oxide (ZnO) & (41) \\
\hline \multicolumn{3}{|c|}{ Chapalichthys pardalis } \\
\hline & Silver (Ag) & (35) \\
\hline \multicolumn{3}{|c|}{ Cyprinodon variegatus } \\
\hline & Copper oxide (CuO) & (24) \\
\hline
\end{tabular}

Cyprinus carpio

Zinc oxide $(\mathrm{ZnO})$

(93)

Danio rerio

Carboxylated polystyrene

Cerium oxide $\left(\mathrm{CeO}_{2}\right)$

Cobalt ferrite $\left(\mathrm{CoFe}_{2} \mathrm{O}_{4}\right)$

Copper (Cu)

Copper oxide (CuO)

Fullerene $\mathrm{C}_{60}$

Graphene oxide (GO)

Gold (Au)

Poly (lactic-co-glycolic acid) (PLGA)

Polyaminoamine (PAMAM)

Silver (Ag)

Silica (Si)

Single wallet carbon nanotubes (SWCNTs)

Titanium dioxide $\left(\mathrm{TiO}_{2}\right)$

Zinc oxide (ZnO)

$(20,21)$

$(66,75,94)$

$(68,95)$

(25)

$(57,79,96)$

$(21,32,60,90,98)$

$(46,47,50)$

$(37,92)$

$(92,95)$

$(73,74,99)$

Dicentrarchus labrax

Titanium dioxide $\left(\mathrm{TiO}_{2}\right)$

$(62,91)$

Epinephelus coioides

Copper (Cu)

$(65,77)$

$(65,77)$

\section{Gobiocypris rarus}

CulnS $_{2}$ quantum dots (CulnS 2 QDs)

(78)

(78)

Ictalurus punctatus

Cobalt oxide $\left(\mathrm{CO}_{3} \mathrm{O}_{4}\right)$

(64)

Copper oxide ( $\mathrm{CuO}$ )

Titanium dioxide $\left(\mathrm{TiO}_{2}\right)$

Zinc oxide ( $\mathrm{ZnO})$

(64)

(64)

(64)

Labeo rohita

Silver (Ag)

$(30,82)$

Micropterus salmoides

Fullerenes $\mathrm{C}_{60}$
TABLE 2 | Continued

\begin{tabular}{|c|c|c|}
\hline Species & Nanoparticles & References \\
\hline \multicolumn{3}{|c|}{ Oreochromis mossambicus } \\
\hline & Iron oxide $\left(\mathrm{Fe}_{2} \mathrm{O}_{4}\right)$ & $(100)$ \\
\hline \multicolumn{3}{|c|}{ Oncorhynchus mykiss } \\
\hline & Cadmium sulfate quantum dots (CdS QDs) & $(54,55)$ \\
\hline & $\begin{array}{l}\text { Cadmiun telluride quantum dots (Cd-Te } \\
\text { QDs) }\end{array}$ & $(51,54,55)$ \\
\hline & Copper (Cu) & (43) \\
\hline & Copper oxide (CuO) & (52) \\
\hline & Gold (Au) & $(43,69)$ \\
\hline & Carbon nanotubes (CNTs) & (89) \\
\hline & Poly (acrylic acid) & (58) \\
\hline & Silver (Ag) & $\begin{array}{l}(33,34,43,69,87, \\
101)\end{array}$ \\
\hline & Silver nitrate $\left(\mathrm{AgNO}_{3}\right)$ & (34) \\
\hline & Single wallet carbon nanotubes (SWCNTs) & (102) \\
\hline & Titanium dioxide $\left(\mathrm{TiO}_{2}\right)$ & (88) \\
\hline
\end{tabular}

Oncorhynchus tshawytscha

Aluminum oxide $\left(\mathrm{Al}_{2} \mathrm{O}_{3}\right)$
Copper oxide $(\mathrm{CuO})$
Titanium oxide $\left(\mathrm{TiO}_{2}\right)$

Oreochromis niloticus

Copper oxide (CuO)

(23)

Iron oxide $\left(\mathrm{Fe}_{2} \mathrm{O}_{3}\right)$

(27)

Multi walled carbon nanotubes (MWCNTs)

Silver (Ag)

Zinc oxide (ZnO)

$(61,103)$

(40)

Oryzias latipes

Graphene- Titanium dioxide $\left(\mathrm{GTiO}_{2}\right)$

Iron (Fe)

$(70,84)$

Silver (Au)

$(72,105)$

Titanium dioxide $\left(\mathrm{TiO}_{2}\right)$

(104)

Paracheirodon axelrodi

Copper oxide (CuO)

(22)

Pimephales promelas

Hydroxylated fullerenes $\left(\mathrm{C}_{60}(\mathrm{OH})_{24}\right)$

Polycarbonate

(45)

Polystyrene

(45)

Titanium dioxide $\left(\mathrm{TiO}_{2}\right)$

$(48,63)$

Poecilia reticulata

Iron oxide $\left(\mathrm{Fe}_{2} \mathrm{O}_{3}\right)$

(49)

Poeciliopsis lucida

Polyamidoamine (PAMAM)

Zinc oxide (ZnO)

(106)

Prochilodus lineatus

Titanium dioxide $\left(\mathrm{TiO}_{2}\right)$

(39)

Scophthalmus maximus

Silver (Ag)

Sparus aurata

Gold (Au)

$(17,26,80,81)$

Trachinotus carolinus

Titanium dioxide $\left(\mathrm{TiO}_{2}\right)$

(53) 
in gills such as hyperplasia and inflammation after exposure of $\mathrm{Ag}$ NPs for 4 and 21 days at different concentrations (1.5-15 $\mu \mathrm{g} / \mathrm{L})(31,36,123)$. Other studies showed lack of pathology in gills after 28 days at Ag NPs concentrations between $10 \mu \mathrm{g} / \mathrm{L}$ and $1 \mathrm{mg} / \mathrm{L}(21,32)$. These gill lesions would affect oxygen intake, osmoregulation, acid-base balance, and excretion of nitrogenous waste that in turn would likely produce acute toxicity (117). As a first line of contact between the host and its environment, one would expect gills to offer an optimal site to assess NP bioaccumulation. However, different studies showed that gills are not the main target for NP accumulation. For example, Oreochromis niloticus exposed to iron oxide $\mathrm{NPs}\left(\mathrm{Fe}_{2} \mathrm{O}_{3}\right)$ for 60 days showed greatest bioaccumulation in the spleen whereas gills displayed much lower levels of bioaccumulation (spleen $>$ intestine $>$ kidney $>$ liver $>$ gills $>$ brain $>$ and muscle) (27). Another study also using O. niloticus but exposed to copper NPs $(\mathrm{Cu})$ for 30 days yielded a similar conclusion (bioaccumulation levels: liver $>$ kidney $>$ gills $>$ skin $>$ and muscle) (23). Bruneau et al. also described a higher bioaccumulation in liver than in gills in O. mykiss after an exposure of Ag NPs for 4 days (34). Thus, although NPs can be absorbed by the gills, they are not the preferred uptake route in teleosts (124). In general, histopathology, and NP bioaccumulation in gills might not be the best biomarker of NPs toxicity. They must be complemented with others potential biomarkers for NPs. For example, the number of goblet cells or mucus production are relevant biomarkers in aquatic toxicology that can be tested to evaluate NPs effects on fish health (117).

\section{CELLULAR RESPONSE}

\section{Leukocytes}

Immune cells play a pivotal role in the clearance of pathogens or other foreign elements like NPs (125). Thus, assessment of leukocyte engagement may provide insights into NP toxicity. Indeed, kidney NP bioaccumulation is linked to a reduction in neutrophils function and a possible reduction in their ability to control bacterial infections (48). In this section, we review recent reports on the effects of NPs on the dynamics and functionality of fish leukocytes (also summarized in Table 1). Additional effects on leukocyte responses will be addressed in the following sections (refer to Internalization of nanoparticles, Oxidative stress, and Cytokines sections).

\section{Macrophages}

Resident macrophages offer early detection of insults (e.g., pathogen infiltration, tissue damage, toxicant exposure) at various tissue sites $(126,127)$. Changes of macrophage viability and function have long been implicated with toxicity resulting from exogenous pollutants (e.g., metals, sewage, hormones disrupting compounds, pharmaceuticals chemicals) $(12,110$, 128). Thus, macrophages and their proper function can be used as biomarkers for immunotoxicity (12). Most recently, this modulation in macrophage function has been used as biomarkers to evaluate NPs toxicity (Table 1). For instance, $\mathrm{TiO}_{2} \mathrm{NPs}$ induced upregulation of macrophage colony-stimulating factor 1 (MCSF-1) in multiple pooled tissues of $P$. promelas (anterior kidney, liver, spleen and gills) (48). Changes in MCSF-1 gene expression have been associated with impairment of macrophage function. This is consistent with its important role in viability, differentiation, mobilization, and activation of macrophages and their precursors (48). Using an in vitro approach, the effect of carbon nanotubes on kidney mix population of macrophages in O. mykiss revealed that SWCNT induces upregulation of pro-inflammatory cytokine expression such as IL-1 $\beta$ but not in IFN $\alpha$ expression, indicating a selective pathway (89). These results suggest a different effect in pro-inflammatory soluble mediators. Duan et al. evaluated the effect of sublethal increasing concentrations of silica NPs $(\mathrm{Si})$ on macrophage function using zebrafish embryos (50). Results showed a downregulation of gene expression in macrophage inhibitory factor (MIF) and vascular endothelial growth factor receptor 2 (VEGFR2). The higher Si NP concentration, the stronger the down regulatory effect resulting in a decrease in macrophage activity (50). These results showed that even at sublethal doses of NPs, macrophage gene expression may provide useful read-outs for evaluation of fish immunity. Melanomacrophages are highly pigmented macrophage type that possess phagocytic function and play an important role in the immune response (129). Melanomacrophage centers (MMCs) have been used as biomarkers to assess fish health and aquatic environmental pollution (130-132). In this context, using the $P$. reticulata model, it has been shown that citrate-functionalized maghemite $\left(\gamma-\mathrm{Fe}_{2} \mathrm{O}_{3}\right)$ induces significant changes in MMCs in liver. Acute (3-7 days) and chronic exposure (14-21 days) to $\gamma-\mathrm{Fe}_{2} \mathrm{O}_{3}$ NPs increase number, cellular content and size in MMCs, suggesting that $\gamma-\mathrm{Fe}_{2} \mathrm{O}_{3}$ might be involved in the regulation of innate immune responses (49). Altogether, these demonstrates that NPs are capable of interfering with multiple aspect of macrophage function (4). Due to the limited number of observations on the responses of MCSF-1, gene expression of pro-inflammatory cytokines, and immune-related genes, and MMCs, these parameters cannot yet be considered as valid biomarkers for NPs toxicity purposes. However, the key role of these parameters in macrophage function motivates continued research on its feasibility as a biomarker.

\section{Neutrophils}

Neutrophils are polymorphonuclear leukocytes that are central to the induction and regulation of acute inflammation (133, 134). Neutrophils act as the predominant phagocytic cells for first-line defense to be recruited to an inflammatory site against diverse xenobiotics $(135,136)$. Thus, neutrophils play an important role in recognizing and eliminating foreign agents, including some NPs (137). In this regard, NPs have been shown to not only impair neutrophil functionality but also affect a diverse array of biochemical responses. These effect in neutrophils features have been used as biomarkers to evaluated NPs toxicity (Table 1). However, based on these studies, there is little clarity to date on the effects of NPs on neutrophil biology. For example, fullerenes have shown to inhibits some function such as ROS production and NETosis in mixed neutrophil populations from kidney of $P$. promelas (44). Interestingly, this effect did not induce significant changes in total neutrophil counts, suggesting that neutrophil antimicrobial functions are 
the primarily affected following fullerene internalization rather than neutrophil development per se (44). On the other hand, Jovanovic et al. revealed that $\mathrm{TiO}_{2}$ NPs injections in $D$. rerio increased neutrophil migration, oxidative burst and phagocytic activity, associated to higher tissue damage $(48,95)$. In this context, increased neutrophil activation can be associated to phosphorylation of p38 mitogen-activated protein kinase (MAPK) and extracellular signal-regulated kinases. Conversely, $\mathrm{TiO}_{2}$ NPs downregulated matrix metalloproteinase 9 (neutrophil elastase) expression, which further decreased IL-8 neutrophil mobilization from hematopoietic tissues (95). Małaczewska and Siwicki et al. found that even when Ag NPs did not induce an effect on peripheral neutrophils, spleen phagocytic activity was inhibited only at high concentrations of Ag NPs using the O. mykiss model (43). These results might be attributed to differences in concentration and time of exposure (43). Ortega et al. used PAA functionalized NPs [cerium oxide $\left(\mathrm{CeO}_{2}\right), \mathrm{TiO}_{2}$, $\mathrm{Fe}_{2} \mathrm{O}_{3}$ and zinc oxide $\left.(\mathrm{ZnO})\right]$ to evaluate their effect on function of a mixed neutrophil population of kidney in Carassius auratus (42). Here, it was shown that NPs decreased neutrophil viability in a concentration and time-dependent manner. Additionally, lower concentration of NPs decreased neutrophil degranulation, and increased ROS production along with an increase of gene expression of pro- and anti-inflammatory cytokines in neutrophils such as IL-1 $\beta$ and IFN $\alpha$. Hence, these sub-lethal doses of NPs might be linked to a higher susceptibility against pathogens and might thus impair fish health (42). Altogether, these studies reveal that several neutrophil functions can be modulated following NPs exposure. However, depending upon the type of NPs evaluated, different results can be observed. Based on the small number of studies to date, it is difficult to estimate the reproducibility of these findings and the reliability of each neutrophil function as biomarkers. Nevertheless, any disruption in neutrophil function will represent major implication of fish immune defenses. Therefore, more studies are needed to clarify if these neutrophil parameters could be used as biomarker to monitor NPs toxicity in fish.

\section{Lymphocytes}

Lymphocytes offer a diverse array of effector and regulatory functions in multiple tissues. They are typically associated to long-term immune responses; however, a wide group of lymphocytes has relevance in innate defenses. For instance, phagocytic B lymphocytes participate in initial responses following pathogen invasion (138). Furthermore, innate lymphoid cells (ILCs) like cells, a recently described group in zebrafish (139), have a role in inflammation, tissue remodeling, and homeostasis regulation $(140,141)$. Thus, lymphocyte development, viability and proper function have a novel potential as biomarker for NP toxicity. For example, O. mykiss exposed to Ag NPs, Au NPs and Cu NPs revealed a differential effect on lymphocytes isolated from blood and spleen by density gradient separation. Lymphocyte viability was decreased only by Ag NPs following two-day incubation. However, no effect on lymphocyte proliferation was observed at the same concentration while enhanced proliferation rates were stimulated with lower concentration of Ag NPs. Conversely, Au NPs had the strongest effect on lymphocyte proliferation within the NPs tested (43). In addition to the effect of NPs on lymphocyte viability and proliferation, there are descriptions of interaction with other pollutants that potentiate their overall effect. For example, in vivo exposure of Dicentrarchus labrax to $\mathrm{TiO}_{2} \mathrm{NPs}$, showed a cytotoxic effect when it interacted with dioxins in splenocytes, suggesting that the spleen might be a possible biomarker for NP toxicity due to NP bioaccumulation in this tissue $(53,91)$. These changes in lymphocyte development will further promote changes in the overall total lymphocyte counts. This was shown by Khabbazi et al. who found significant differences in lymphocytes counts in blood in O. mykiss exposed to copper oxide NPs (CuO) (52). On the other hand, P. promelas exposed to hydroxylated fullerenes or $\mathrm{TiO}_{2}$ NPs did not produce differences in lymphocytes counts in blood samples $(44,48)$. Due to the limited number of studies and notable difference between results in viability and lymphocyte counts after an exposure with NPs, these parameters cannot yet be considered as biomarkers to assess NPs toxicity. Although most studies discussed here used morphological approaches for lymphocyte definition, further studies are needed for deeper and more accurate characterization of lymphocyte subsets in fish and their specific contribution in NP toxicity.

\section{Internalization of Nanoparticles}

Internalization of invading pathogens or threats is the paramount to immune defense in several organisms. In the case of NP, their size, shape, surface chemistry, and mechanical properties influences the mechanism of cellular internalization $(142,143)$. For example, following entry, small NPs $(<100 \mathrm{~nm})$ are rapidly internalized by professional cells through endocytosis whereas large NPs (larger than $500 \mathrm{~nm}$ ) are uptaken by micropinocytosis or phagocytosis $(34,144)$. Thus, despite their origin and internalization processes, NPs have been shown to modulate cellular responses in a variety of professional phagocytes such as neutrophils, monocyte, and macrophages (43). For instance, Malaczewska and Siwicki evaluated the effect of Ag NPs, Au NPs and $\mathrm{Cu}$ NPs on the phagocytic activity of spleen leukocytes from O. mykiss, showing an increase in phagocytic capacity in fish exposed to Ag NPs, but not observed in animals exposed to Au NPs nor Cu NPs (43). Through intraperitoneal injections, $\mathrm{TiO}_{2}$ NPs were administrated to Trachinotus carolinus and cellular uptake was evaluated after 3 days. Results demonstrated NP uptake in the liver, kidney, lung, and spleen following a similar process that is also observed in mice and human cells (145, 146). However, the authors suggested that other internalization processes might occur in fish other than phagocytosis since they detected $\mathrm{TiO}_{2}$ NPs reaching the nucleus compartment. Bruneau et al. have shown that cadmium tellurium quantum dots (CdTeQDs) induce an increase in phagocytosis rates associated to the size and form of those NPs in O. mykiss (51). In a different experiment, Greven et al. demonstrated that aggregation of polystyrene and polycarbonate nanoplastic particles promotes NPs internalization in $P$. promelas (45). As described, NP induced significant changes in the capacity of leukocytes to perform internalization of NPs. This suggests a regulatory effect, occurring in a time, and concentration-dependent manner, that 
is associated to the type of NP. Studies summarized here suggest that internalization of NPs by phagocytic cells, is a potential biomarker that can offer relevant information about the effect of the NPs at the intracellular level and should be complemented with other biomarkers to gain an integrative view of altered cellular function.

\section{Oxidative Stress}

Once NPs have gained access to the organism, distributed to multiple tissues, and internalized into cells, they are capable to promote intracellular responses such as oxidative stress. Oxidative stress refers to the imbalance between the production of free radicals and the protective antioxidant defense system (109, 147). Oxidative stress has become a relevant biomarker for aquatic toxicology (148), because this phenomenon in fish can be triggered by many chemicals including NPs, metal ions, pesticides, oil products, and chlorinated hydrocarbons (9, 95, 109-111). These environmental pollutants can induce oxidative stress in fish via two ways: directly by affecting the animals or indirectly by modifying the environmental conditions (111). Oxidative stress can be detected and measured giving a quantitative indication of fish health status and it can be evaluated using different parameters such as free radicals, antioxidant defenses and biomarkers of oxidative stress (Table 1).

\section{Reactive Oxygen Species and Nitric Oxide}

ROS are free radicals formed as a natural by-product of the normal metabolism of oxygen. ROS have important roles in cell signaling and homeostasis (149). However, ROS may significantly increase under stressful scenarios such as infection, inflammation, and exposure to environmental pollutants (111, 150). This increase may disrupt homeostasis, producing damage at the cellular level, and disease or death at the organism level $(109,148)$. ROS has been one of the most common parameters used for the evaluation of fish health after exposure to different types of NPs (Table 1). The preference of ROS as a biomarker is attributed to: (i) its high sensitivity to different NP exposure; (ii) fast-triggered response compared to other free radicals; (iii) remarkable consistency of results between studies; and (iv) increasing development of novel highly-sensitive reagents that allow the detection of slight changes of ROS production. NPs that have been shown to induce ROS production in fish include carbon-based, metal-based, plastic-based, and polymeric carrier NPs.

Levels of ROS have been successfully measured after exposure to NPs in different fish species such as D. rerio $(25,37,46,56,60$, $66,68,73,74,94)$, P. promelas $(44,45,48)$, Oryzias latipes $(70,72)$, Poeciliopsis lucida $(71,106)$, O. niloticus $(27,40)$, C. auratus (42), O. mykiss (43), Oncorhynchus tshawytscha (67), Epinephelus coioides (65), Ictalurus punctatus (64), Anguilla anguilla (29), Apistogramma agassizii (22), Paracheirodon axelrodi (22), and Prochilodus lineatus (39). Interestingly, these studies showed a high versatility of ROS that can be measured in different stage of fish development, tissues, and cells. Most studies using embryos $(46,47,56,66,73,74)$ and larvae (70) observed an increase of ROS levels. However, an exception were those studies using $\mathrm{Si}$ NPs where no effect was observed in embryos $(46,47)$. These authors claimed that the lack of increase in ROS levels was related to the type of NP used (47). The use of embryo/larvae models to analyze ROS levels confer an integrative view of whole organism response. Even when some studies showed that no effect was observed in ROS levels, use of embryos/larvae confer a low cost and easy handling tool that still make them valuable as biomarkers. In the case of adult fish exposed to NPs, there are studies that assess ROS production in whole organs. ROS have been measured in different tissues such as gills $(22,25,37,39)$, liver (37), intestine (37), and brain (37), and fluids as serum (27, 40). Using gills, different studies showed a persistent ROS activation after NP exposure. For instance, A. agassizii exposed to $\mathrm{Cu}$ NPs showed greatest increase in ROS production at 3 days of exposure (22). Souza Khabbazi et al. observed a significant increase in ROS levels at day 1 of exposure with graphene oxide (GO) in gills of zebrafish (25). As first line of contact between the host and NPs, one would expect gills to offer a faster biomarker than internal organs. However, a study also using zebrafish but exposed to SWCNT showed a significant increase in ROS production in gills at 3 days of exposure comparatively slower than in liver and brain, where this increase was at 2 days (37). No modulatory effect was observed in the intestine (37). The available information reveals that measurement of ROS in gills is a valid biomarker to assess NPs toxicity, even though time of response can be slower than other organs. Furthermore, ROS production have been evaluated in vitro using both cell lines and primary cell cultures. These studies took advantage of a large variety of cell types such as: zebrafish liver (ZFL) $(60,68,94)$; PLHC-1 derived from hepatocellular carcinoma in P. lucida (71, 106); and CHSE-214 derived from O. tshawytscha embryo (67); and primary cell cultures such as: neutrophils (42, 44, 45, 48); hepatocytes $(64,65,69)$; splenocytes (43) and phagocytes (29). In cell lines, different NPs, concentrations, and exposure time, increased ROS levels. In contrast, not all NPs successfully modulate ROS production in primary cell cultures $(42,69)$. These results reveal that ROS production in cell lines, as per their homogeneous nature, is more consistent than in primary cell-based assays. This might be attributed to factors such as heterogeneity, cellular viability, and activation state of primary cells. Diverse studies have been done on a wide range of fish species and targets that can be used to test NPs effect on ROS production. These studies point out ROS as a reliable, sensitive, and valid biomarker of NPs toxicity in fish.

$\mathrm{NO}$ is the second free radical used as a biomarker to assess NPs toxic effects in fish described in literature. NO is produced by inducible nitric oxide synthase (iNOS). iNOS converts L-arginine and oxygen into L-citrulline and NO (151). NO may produce a wide range of physiological and pathophysiological effects (152). In contrast to ROS, there are only two studies which have evaluated NO expression in fish after exposure to NPs (Table 1). Based on these studies, it appears that NO may also serve as a useful biomarker. In the first study, zebrafish embryos exposed to $\mathrm{CuO}$ NPs showed a significant increase in NO production. Interestingly, the same increasing trends were observed for ROS production (66). In a second study, also using zebrafish embryos two NPs were analyzed, $\mathrm{CuO}$ NPs, and $\mathrm{CeO}_{2}$ NPs. CuO NPs increased $\mathrm{NO}$ levels in contrast to $\mathrm{CeO}_{2} \mathrm{NPs}$ that decreased them 
(75). The authors explained that this difference was due to the high toxicity of $\mathrm{CuO}$ and the ability of Ce to scavenge $\mathrm{NO}$ (75). The low number of studies that focus on NO production may be due to the response rate of this free radical, where ROS levels have been shown to respond faster than NO. As mentioned above, NO levels need to be produced by iNOS expression and this specific pathway is slower than ROS production (153). As showed above, since only two studies analyze the effect on NO more research is required to determine its potential use as a biomarker in the context of NPs toxicity. Among other, evaluation of diverse NPs at different concentrations that can confirm that NO reproducibility of the results.

\section{Antioxidant Defenses}

Free radical levels can be balanced by the antioxidant system which scavenges free radicals and delays or inhibits cellular damage $(154,155)$. There is a wide range of antioxidant defenses as diverse as free radicals themselves (156). Antioxidant defenses have been widely used as biomarkers of environmental toxicology $(11,109)$. Different antioxidants have been analyzed as tools to measure the effects of NPs on fish health (Table 1). The three main antioxidants and direct free radical scavengers include superoxide dismutase (SOD), catalase (CAT), and glutathione peroxidase (GPx). Other antioxidant enzymes that inactivate secondary metabolites have been measured to evaluate the effects of NPs on fish health such as glutathione sulfotransferase (GST), total glutathione (GSH), glutathione in its reduced state (GR), and its oxidized state (GSSG) $(157,158)$ (Table 1). Antioxidant levels have been measured mainly by biochemical assays but also by gene expression studies $(65,70,79-81)$. As a homeostasis system, we would expect that antioxidants defenses levels increase after NPs exposure. However, some studies showed that antioxidants defenses do not always showed these patterns. For instance, Srikanth et al. used chinook salmon cells (CHSE-214) exposed to $\mathrm{CuO}$ NPs, they found a significant increase in ROS, SOD, CAT and GPx levels as expected (67). In contrast, Ganesan et al. observed a marked decrease in antioxidant defenses (SOD, CAT and GPx) in zebrafish embryos after exposure to $\mathrm{CuO}$ NPs, however, ROS levels showed significant increases (66). The authors claimed that the antioxidant system was overpowered by increased ROS production (66). Despite that multiple studies have used only antioxidant defenses to assess fish health following NPs exposure (30,34, 41, 59, 76, 77, 79-83), we point out that antioxidant defenses should be measured as a complement of ROS and not by themselves.

\section{Biomarkers of Oxidative Stress}

NPs are potent triggers of oxidative stress in fish and this can be detected through the measurement of molecular biomarkers. However, no single biomarker has been identified as sensitive and specific enough to detect oxidative stress alone (159). Generally, products of cells with oxidative stress or tissue damage are observed after exposure to NPs. Examples of these are malondialdehyde (MDA), lipid peroxidation (LPO), myeloperoxidase activity (MPO) and protein carbonyl (PC) (Table 1). As expected, these biomarkers display similar patterns of ROS production. For example, zebrafish larvae exposed to
ZnO NPs showed a significant increase in ROS and MDA levels at different concentrations (73). Ganesan et al. reported similar results: an increase in ROS, NO, and biomarkers such as LPO and PC in zebrafish embryos after exposure to $\mathrm{CuO}$ NPs (66). Using an in vivo approach with $\mathrm{ZnO}$ NPs, plasma in O. niloticus revealed that both small and large NPs incremented both ROS and MPO levels, showing a clear activation of oxidative stress (40). Biomarkers of oxidative stress have lower specificity for NP toxicity (159), thus, they should be used to complement ROS and antioxidant defenses results following NP exposure.

\section{Cytokines}

Cytokines are small proteins produced by immune cells that act as signaling molecules within the immune system (160). Thus, cytokines regulate inflammatory signals against pathogens or any external agent such as NPs. This modulation of cytokine expression has been used to assess fish health following NPs exposure and mainly through molecular assays such as $\mathrm{qPCR}$ (Table 1). The rising number of studies evaluating cytokine gene expression in NPs toxicity context is likely related to the increasing cost effectiveness and availability of molecular techniques such as $\mathrm{qPCR}$, and the rapid progress in the sequencing of fish cytokines (161-164). In this regard, exposure of $S$. aurata to Au NPs causes altered gene expression in head kidney (80), when pro-inflammatory cytokines such as IL-1 $\beta$ and TNF $\alpha$ were upregulated after 4 days exposure. Interestingly, through the same technique, authors observed an increase in oxidative stress in head kidney (80). Picchietti et al. observed an increase in IL-8 and TGF- $\beta$ expression, and internalization of $\mathrm{TiO}_{2}$ NPs in DLEC cells (a cell line established from D. labrax) after 1 day of exposure (62). Another study observed upregulated expression of IL-1 $\beta$ and TNF- $\alpha$ in intestine of E. coioides after exposure to $\mathrm{Cu}$ NPs for 25 days (77). Together, these results showed that cytokine gene expression is sensitive to NP exposure. Hence, cytokines emerge as a possible biomarker for monitoring the impact of NPs on overall fish health, since current methodologies provide sensitive platforms to assess variations at the molecular levels.

\section{Lysozyme}

Lysozyme is a relevant defense component of the innate immune system through its antibacterial activity. Furthermore, lysozyme can also act as an opsonin and activate complement system and phagocytes (165). It is widely distributed in mucus, plasma, kidney, spleen, intestine, and gills (166-168). Lysozyme activity in plasma or serum is a standard ecotoxicological biomarker in fish (169). However, to date there are only three studies which have evaluated lysozyme activity in fish after exposure to NPs (Table 1). For example, E. coioides exposed to $\mathrm{Cu}$ NPs and copper sulfate NPs $\left(\mathrm{CuSO}_{4}\right)$ revealed diminished lysozyme activity in the intestine after 25 days (77). This suppressive effect was also observed in blood samples in O. niloticus exposed to $\mathrm{Fe}_{2} \mathrm{O}_{3} \mathrm{NPs}$ after 60 days (27). In another study, this decrease in lysozyme activity in the serum was only observed for large ZnO NPs at the lowest concentration on day 14 (40). Some studies have described that lysozyme are able to bind metal oxide NPs $(170,171)$ producing a decrease of lysozyme activity (171). Thus, NPs have 


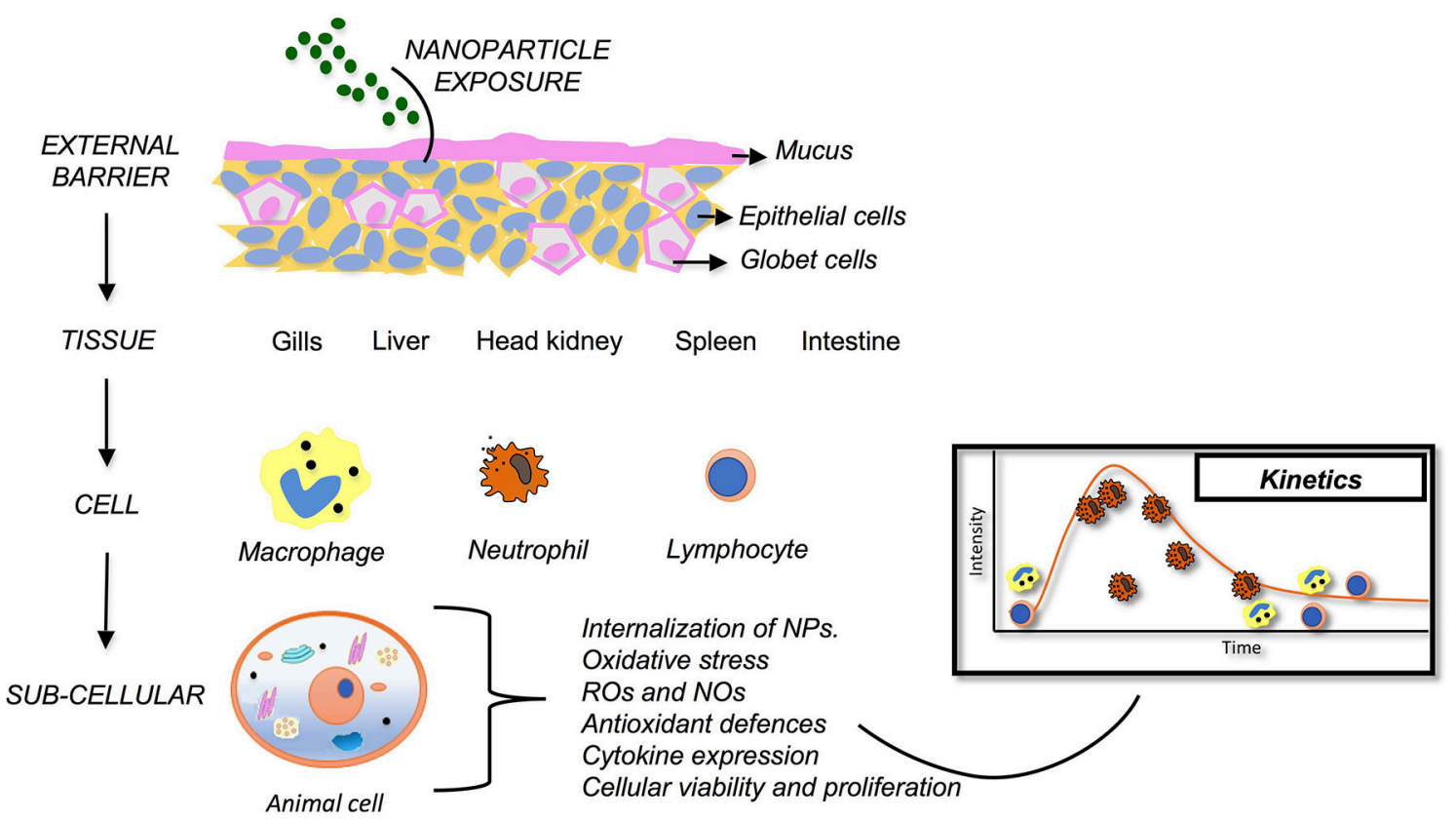

FIGURE 1 | Innate immunity as a bioindicator of health for teleost fish exposed to nanoparticles. Following NP exposure, fish immunity is evident at different levels (external barriers, tissue, cellular and sub-cellular). Each provides unique insights into changes to homeostasis and, thus, can be used to detect nanoparticle-induced immunotoxicity.

a suppressor effect on lysozyme activity in fish. Hence, lysozyme activity represents a good indicator of immunosuppression that NPs can cause in fish. However, more research is needed to show the effectiveness of lysozyme as a biomarker due to the limited number of existing studies until today. Among others, analysis using different species, tissues (e.g., mucus on the skin), NPs and concentration of NP concurrently are needed to support consistent results. Ideally, performing a pathogen challenge after NP exposure would be best to assess the complete effect of NPmediated lysozyme suppression on fish response to pathogen exposure.

\section{INDUSTRIAL POINT OF VIEW}

The industrial production of engineered NPs has grown at a considerable rate with an increasing number of commercial products utilizing them, which includes; paints, fabrics, cosmetics, treated wood, electronics, and sunscreen (172). Established in 2005, the Nanotechnology Consumer Products Inventory (CPI) listed 54 consumer products containing nanomaterials. Over 1,800 products from 622 companies in 32 countries are currently inventoried (173).

The rate of development for environmental exposure limits and monitoring policies has been surpassed by the growth rate of this emerging class of pollutants. The resulting gap in regulations for engineered NP has been identified as a key focus area in Europe and the United States through the European Commission and the National Institute for Occupational Safety and Health, respectively (174). Monitoring methodology able to detect NPs present in the environment is very limited, combined with inherent challenges for sampling, creating barriers in the ability to distinguish adverse effects (175).

To complement biological read-outs as those described above, analytical techniques used to measure regulated compounds typically rely on reactive potential within a closed system (i.e., conductivity, polarity, bond with coloring agent) thus allowing for cost effective high throughput production of samples. Required detection limits for NP's reduces options to highly sensitive instrumentation i.e., field-flow fractionation, sizeexclusion chromatography, liquid chromatography, transmission electron microscopy (TEM), and atomic force microscopy (AFM) (176). Cost restrictions and equipment infrastructure are limitations preventing methodology viability.

Alternative methods based on bioanalytics are not bound by individual chemical structures, which enables them to assess the net effect on whole biological systems (177). The European Environment Agency (EEA) and the Australian Governments National Water Initiative (AU NWI) have directed significant resources to the evaluation of biology-based monitoring tools to ensure water quality. The European Union Water Framework Directive (EU WFD) and the Australian Governments National Urban Water and Desalination Plan have both found that bioanalytics offered a distinct advantage as a monitoring tool offering the only read-out that integrates the effects of complex mixtures during evaluation of water quality on important ecosystem functioning (177). Interactions of NPs with the innate immune system of fish elicit a number of several, quantifiable, and reproducible responses such as ROS, antioxidants defenses, 
internalization of NPs, and cytokine production. Therefore, biomarkers based on innate immune responses offers significant opportunities for the development of robust methodologies that can provide functional biological outputs assessing the health of an aquatic ecosystem following exposure to a variety of NPs.

\section{CONCLUDING REMARKS}

The literature summarized here explores a range of possible innate immune biomarkers as tools for the assessment of fish health following NP exposure. These biomarkers reveal multiple alterations produced by NPs into diverse organs and tissues in multiple fish species (Figure 1). To date, oxidative stress is the most widely innate immune biomarker studied to demonstrate NPs toxicity in fish, particularly using the measurement of ROS, and antioxidant defenses. This is attributed to its high sensitivity to NPs exposure and the remarkable consistency of results among studies on a wide range of fish species and targets. These studies pointed out ROS and antioxidants defenses as a reliable, sensitive, and valid biomarkers of NPs toxicity in fish. Additionally, this review reveals other potential biomarkers that can be used to evaluated fish health following NPs exposure. For example, analysis of mucus on the skin, leukocyte functionality (macrophages and neutrophils), internalization of NPs, cytokine expression, and lysozyme levels. These potential biomarkers showed significantly promising results, although, more research is needed to determine their consistency and reliability. Furthermore, some innate immune parameters used on current literature are not valid options as biomarkers to evaluated NPs toxicity. For example, histopathology, and NP bioaccumulation in gills and biomarkers of oxidative stress. These parameters

\section{REFERENCES}

1. Rather M, Bhat I, Sharma N, Sharma R. 16. Molecular and cellular toxicology of nanomaterials with related to aquatic organisms. In: Saquib Q, Faisal M, AL-Khedhairy A, Alatar A, editors. Cellular and Molecular Toxicology of Nanoparticles. Cham: Springer (2018). p. 263-84.

2. Jeevanandam J, Barhoum A, Chan YS, Dufresne A, Danquah MK. Review on nanoparticles and nanostructured materials: history, sources, toxicity and regulations. Beilstein J Nanotechnol. (2018) 9:1050-74. doi: 10.3762/bjnano.9.98

3. Bondarenko $\mathrm{O}$, Juganson $\mathrm{K}$, Ivask $\mathrm{A}$, Kasemets $\mathrm{K}$, Mortimer $\mathrm{M}$, Kahru A. Toxicity of $\mathrm{Ag}, \mathrm{CuO}$ and $\mathrm{ZnO}$ nanoparticles to selected environmentally relevant test organisms and mammalian cells in vitro: a critical review. Arch Toxicol. (2013) 87:1181-200. doi: 10.1007/s00204-0131079-4

4. Jovanovic B, Palic D. Immunotoxicology of non-functionalized engineered nanoparticles in aquatic organisms with special emphasis on fish-review of current knowledge, gap identification, and call for further research. Aquat Toxicol. (2012) 118-119:141-51. doi: 10.1016/j.aquatox.2012. 04.005

5. Scown TM, van Aerle R, Tyler CR. Review: Do engineered nanoparticles pose a significant threat to the aquatic environment? Crit Rev Toxicol. (2010) 40:653-70. doi: 10.3109/10408444.2010.494174

6. Nowack B, Bucheli TD. Occurrence, behavior and effects of nanoparticles in the environment. Environ Pollut. (2007) 150:5-22. doi: 10.1016/j.envpol.2007.06.006 do not provide accurate and relevant information in NPs toxicity context. Despite these considerations, industry needs biomarkers as tracking tools to evaluate NPs toxicity, because analytical techniques present cost restrictions and equipment infrastructure limitations that constraint methodologies viability. In conclusion, it can be stated that innate immune biomarkers are promising tools to assess fish health following NPs exposure. However, much work must be done in order to test and interpret some of biomarkers responses present in this review. Based on the diversity of these parameters, the number of studies analyzing NP effects in fish is yet limited. Further studies on the impact of NPs will provide a better understanding of detrimental effects of NPs to fish health.

\section{AUTHOR CONTRIBUTIONS}

The conceptualization of the review was performed by DT and DB. DT was the primary writing contributor to this review. JM-B and JW wrote and edited parts of the manuscript. DT and DB edited the final manuscript. All authors approved the final version of the manuscript.

\section{ACKNOWLEDGMENTS}

DT was supported by a CONICYT-Chile postdoctoral fellowship (Becas Chile $\mathrm{N}^{\circ}$ 74170029). JM-B was supported by a National Fund for Innovation in Science and Technology (FINCyT/Innovate-Peru) scholarship and a Graduate Teaching Assistantship by the Department of Biological Sciences at the University of Alberta. This work was supported by an NSERC Discovery grant RGPIN-2018-05768 (Canada) to DB.

7. Callaghan NI, MacCormack TJ. Ecophysiological perspectives on engineered nanomaterial toxicity in fish and crustaceans. Comp Biochem Physiol C Toxicol Pharmacol. (2017) 193:30-41. doi: 10.1016/j.cbpc.2016.12.007.

8. Handy RD, Owen R, Valsami-Jones E. The ecotoxicology of nanoparticles and nanomaterials: current status, knowledge gaps, challenges, and future needs. Ecotoxicology (2008) 17:315-25. doi: 10.1007/s10646-008-0206-0.

9. Moore $\mathrm{MN}$. Do nanoparticles present ecotoxicological risks for the health of the aquatic environment? Environ Int. (2006) 32:967-76. doi: 10.1016/j.envint.2006.06.014.

10. Powers D. Fish as model system. Science (1989) 246:352-8.

11. van der Oost R, Beyer J, Vermeulen N. Fish bioaccumulation and biomarkers in environmental risk assessment: a review. Environ Toxicol Pharmacol. (2003) 13:57-149. doi: 10.1016/S1382-6689(02)00126-6

12. Wester P, Vethaak A, Muiswinkel W. Fish as biomarkers in immunotoxicology. Toxicology (1994) 86:213-32.

13. Canada E. Biological test method: acute lethality test using rainbow trout. In: Scroggins R, editors. Canada: The Innate Response Thus Forms a Crucial Component of Biomarkers in the Evaluation of Environmental Health. Ottawa, ON: MdaasETcE (1990). p. 66.

14. Haque E, Ward AC. Zebrafish as a model to evaluate nanoparticle toxicity. Nanomaterials (2018) 8:1-18. doi: 10.3390/nano8070561

15. Lin S, Zhao Y, Nel AE, Lin S. Zebrafish: an in vivo model for nano EHS studies. Small (2013) 9:1608-18. doi: 10.1002/smll.201202115

16. Chakraborty C, Sharma AR, Sharma G, Lee SS. Zebrafish: a complete animal model to enumerate the nanoparticle toxicity. J Nanobiotechnol. (2016) 14:65. doi: 10.1186/s12951-016-0217-6. 
17. Oliveira M, Tvarijonaviciute A, Trindade T, Soares AMVM, Tort L, Teles M. Can non-invasive methods be used to assess effects of nanoparticles in fish? Ecol Indic. (2017) 95:1118-27. doi: 10.1016/j.ecolind.2017.06.023

18. Hawkins AD, Thornton C, Steevens JA, Willett KL. Alteration in Pimephales promelas mucus production after exposure to nanosilver or silver nitrate. Environ Toxicol Chem. (2014) 33:2869-72. doi: 10.1002/etc.2759

19. Benavides M, Fernandez-Lodeiro J, Coelho P, Lodeiro C, Diniz MS. Single and combined effects of aluminum (Al2O3) and zinc $(\mathrm{ZnO})$ oxide nanoparticles in a freshwater fish, Carassius auratus. Environ Sci Pollut Res Int. (2016) 23:24578-91. doi: 10.1007/s11356-016-7915-3.

20. Griffitt R, Weil R, Hyndman K, Denslow N, Powers K, YTaylor D, et al. Exposure to copper nanoparticles causes gill injury and acute lethality in zebrafish (Danio rerio). Environ Sci Technol. (2007) 41:8178-86. doi: 10.1021/es071235e

21. Griffitt R, Hyndman K, Denslow N, Barber D. Comparison of molecular and histological changes in zebrafish gills exposed to metallic nanoparticles. Toxicol Sci. (2009) 107:404-15. doi: 10.1093/toxsci/kfn256

22. Braz-Mota S, Campos DF, MacCormack TJ, Duarte RM, Val AL, AlmeidaVal VMF. Mechanisms of toxic action of copper and copper nanoparticles in two Amazon fish species: Dwarf cichlid (Apistogramma agassizii) and cardinal tetra (Paracheirodon axelrodi). Sci Total Environ. (2018) 630:116880. doi: 10.1016/j.scitotenv.2018.02.216

23. Abdel-Khalek AA, Badran SR, Marie MA. Toxicity evaluation of copper oxide bulk and nanoparticles in Nile tilapia, Oreochromis niloticus, using hematological, bioaccumulation and histological biomarkers. Fish Physiol Biochem. (2016) 42:1225-36. doi: 10.1007/s10695-016-0212-8

24. Ates M, Dugo M, Demir V, Arslan Z, Tchounwou PB. Effect of copper oxide nanopartciles to sheepshead minnow (Cyprinodon variegatus) at different salinities. Dig J Nanomater Biostruct. (2014) 9: 369-77.

25. Souza JP, Baretta JF, Santos F, Paino IMM, Zucolotto V. Toxicological effects of graphene oxide on adult zebrafish (Danio rerio). Aquat Toxicol. (2017) 186:11-8. doi: 10.1016/j.aquatox.2017.02.017

26. Teles M, Reyes-Lopez FE, Fierro-Castro C, Tort L, Soares A, Oliveira M. Modulation of immune genes mRNA levels in mucosal tissues and DNA damage in red blood cells of Sparus aurata by gold nanoparticles. Mar Pollut Bull. (2018) 133:428-35. doi: 10.1016/j.marpolbul.2018. 06.007

27. Ates M, Demir V, Arslan Z, Kaya H, Yilmaz S, Camas M. Chronic exposure of tilapia (Oreochromis niloticus) to iron oxide nanoparticles: effects of particle morphology on accumulation, elimination, hematology and immune responses. Aquat Toxicol. (2016) 177:22-32. doi: 10.1016/j.aquatox.2016.05.005

28. Campos-Garcia J, Martinez DS, Rezende KF, da Silva JR, Alves OL, Barbieri E. Histopathological alterations in the gills of Nile tilapia exposed to carbofuran and multiwalled carbon nanotubes. Ecotoxicol Environ Saf. (2016) 133:481-8. doi: 10.1016/j.ecoenv.2016. 07.041

29. Costa LC, Mohmood I, Trindade T, Saleem M, Duarte AC, Pereira $\mathrm{E}$, et al. Rescheduling the process of nanoparticle removal used for water mercury remediation can increase the risk to aquatic organism: evidence of innate immune functions modulation in European eel (Anguilla anguilla L.). Environ Sci Pollut Res Int. (2015) 22:18574-89. doi: $10.1007 /$ s11356-015-5375-9

30. Shobana C, Rangasamy B, Poopal RK, Renuka S, Ramesh M. Green synthesis of silver nanoparticles using Piper nigrum: tissue-specific bioaccumulation, histopathology, and oxidative stress responses in Indian major carp Labeo rohita. Environ Sci Pollut Res Int. (2018) 25:11812-32. doi: 10.1007/s11356-018-1454-Z

31. Lacave JM, Vicario-Pares U, Bilbao E, Gilliland D, Mura F, Dini L, et al. Waterborne exposure of adult zebrafish to silver nanoparticles and to ionic silver results in differential silver accumulation and effects at cellular and molecular levels. Sci Total Environ. (2018) 642:1209-20. doi: 10.1016/j.scitotenv.2018.06.128

32. Griffit R, Lavelle C, Kane A, Denslow N, Barber D. Chronic nanoparticulate silver exposure results in tissue accumulation and transcriptomic changes in zebrafish. Aquat Toxicol (2013) 130-1:192-200. doi: 10.1016/j.aquatox.2013.01.010
33. Monfared AL, Bahrami AM, Hosseini E, Soltani S, Shaddel M. Effects of Nano-particles on Histo-pathological changes of the fish. J Environ Health Sci Eng. (2015) 13:62. doi: 10.1186/s40201-015-0216-9

34. Bruneau A, Turcotte P, Pilote M, Gagne F, Gagnon C. Fate of silver nanoparticles in wastewater and immunotoxic effects on rainbow trout. Aquat Toxicol. (2016) 174:70-81. doi: 10.1016/j.aquatox.2016.02.013

35. Valerio-Garcia RC, Carbajal-Hernandez AL, Martinez-Ruiz EB, Jarquin-Diaz VH, Haro-Perez C, Martinez-Jeronimo F. Exposure to silver nanoparticles produces oxidative stress and affects macromolecular and metabolic biomarkers in the goodeid fish Chapalichthys pardalis. Sci Total Environ. (2017) 583:308-18. doi: 10.1016/j.scitotenv.2017.01.070

36. Osborne O, Lin S, Chang C, Ji Z, Yu X, Wang X, et al. Organ-specific and sizedependent Ag nanoparticle toxicity in gills and intestines of adult Zebrafish. ACS Nano (2015) 9:9573-84. doi: 10.1021/acsnano.5b04583

37. Li Y, Men B, He Y, Xu H, Liu M, Wang D. Effect of single-wall carbon nanotubes on bioconcentration and toxicity of perfluorooctane sulfonate in zebrafish (Danio rerio). Sci Total Environ. (2017) 607-608:509-18. doi: 10.1016/j.scitotenv.2017.06.140

38. Smith CJ, Shaw BJ, Handy RD. Toxicity of single walled carbon nanotubes to rainbow trout, (Oncorhynchus mykiss): respiratory toxicity, organ pathologies, and other physiological effects. Aquat Toxicol. (2007) 82:94-109. doi: 10.1016/j.aquatox.2007.02.003

39. do Carmo TLL, Azevedo VC, de Siqueira PR, Galvao TD, Dos Santos FA, Dos Reis Martinez CB, et al. Reactive oxygen species and other biochemical and morphological biomarkers in the gills and kidneys of the Neotropical freshwater fish, Prochilodus lineatus, exposed to titanium dioxide (TiO2) nanoparticles. Environ Sci Pollut Res Int. (2018) 25:22963-76. doi: 10.1007/s11356-018-2393-4

40. Kaya H, Aydin F, Gurkan M, Yilmaz S, Ates M, Demir V, et al. A comparative toxicity study between small and large size zinc oxide nanoparticles in tilapia (Oreochromis niloticus): Organ pathologies, osmoregulatory responses and immunological parameters. Chemosphere (2016) 144:571-82. doi: 10.1016/j.chemosphere.2015.09.024

41. Asghar MS, Qureshi NA, Jabeen F, Khan MS, Shakeel M, Chaudhry AS. Ameliorative effects of Selenium in $\mathrm{ZnO}$ NP-induced oxidative stress and hematological alterations in Catla catla. Biol Trace Elem Res. (2018):1-9. doi: 10.1007/s12011-018-1299-9

42. Ortega VA, Katzenback BA, Stafford JL, Belosevic M, Goss GG. Effects of polymer-coated metal oxide nanoparticles on goldfish (Carassius auratus L.) neutrophil viability and function. Nanotoxicology (2015) 9:23-33. doi: 10.3109/17435390.2013.861943

43. Małaczewska J, Siwicki AK. The in vitro effect of commercially available noble metal nanocolloids on the rainbow trout (Oncorhynchus mykiss) leukocyte and splenocyte activity. Pol J Vet Sci. (2013) 16:77-84. doi: 10.2478/pjvs-2013-0011

44. Jovanovic B, Anastasova L, Rowe EW, Palic D. Hydroxylated fullerenes inhibit neutrophil function in fathead minnow (Pimephales promelas Rafinesque, 1820). Aquat Toxicol. (2011) 101:474-82. doi: 10.1016/j.aquatox.2010.11.002.

45. Greven AC, Merk T, Karagoz F, Mohr K, Klapper M, Jovanovic B, et al. Polycarbonate and polystyrene nanoplastic particles act as stressors to the innate immune system of fathead minnow (Pimephales promelas). Environ Toxicol Chem. (2016) 35:3093-100. doi: 10.1002/etc.3501

46. Duan J, Hu H, Li Q, Jiang L, Zou Y, Wang Y, et al. Combined toxicity of silica nanoparticles and methylmercury on cardiovascular system in zebrafish (Danio rerio) embryos. Environ Toxicol Pharmacol. (2016) 44:1207. doi: 10.1016/j.etap.2016.05.004

47. Duan J, Yu Y, Li Y, Wang Y, Sun Z. Inflammatory response and blood hypercoagulable state induced by low level co-exposure with silica nanoparticles and benzo[a]pyrene in zebrafish (Danio rerio) embryos. Chemosphere (2016) 151:152-62. doi: 10.1016/j.chemosphere.2016. 02.079

48. Jovanovic B, Anastasova L, Rowe EW, Zhang Y, Clapp AR, Palic D. Effects of nanosized titanium dioxide on innate immune system of fathead minnow (Pimephales promelas Rafinesque, 1820). Ecotoxicol Environ Saf. (2011) 74:675-83. doi: 10.1016/j.ecoenv.2010.10.017

49. Qualhato G, de Saboia-Morais SMT, Silva LD, Rocha TL. Melanomacrophage response and hepatic histopathologic biomarkers in the guppy Poecilia 
reticulata exposed to iron oxide (maghemite) nanoparticles. Aquat Toxicol. (2018) 198:63-72. doi: 10.1016/j.aquatox.2018.02.014

50. Duan J, Hu H, Feng L, Yang X, Sun Z. Silica nanoparticles inhibit macrophage activity and angiogenesis via VEGFR2-mediated MAPK signaling pathway in zebrafish embryos. Chemosphere (2017) 183:483-90. doi: 10.1016/j.chemosphere.2017.05.138

51. Bruneau A, Fortier M, Gagne F, Gagnon C, Turcotte P, Tayabali A, et al. Size distribution effects of cadmium tellurium quantum dots (CdS/CdTe) immunotoxicity on aquatic organisms. Environ Sci Process Impacts (2013) 15:596. doi: 10.1039/c2em30896g

52. Khabbazi M, Harsij M, Akbar S, Gholipoor H, Hasan M, Ghafari H. Effect of $\mathrm{CuO}$ nanoparticles on some hematological indices of rainbow trout Onchorhynchus mykiss and their potential toxicity. Nanomed J. (2014) 2:6773. doi: $10.7508 / \mathrm{nmj} .2015 .01 .008$

53. Vignardi CP, Hasue FM, Sartorio PV, Cardoso CM, Machado AS, Passos MJ, et al. Genotoxicity, potential cytotoxicity and cell uptake of titanium dioxide nanoparticles in the marine fish Trachinotus carolinus (Linnaeus, 1766). Aquat Toxicol. (2015) 158:218-29. doi: 10.1016/j.aquatox.2014.11.008.

54. Bruneau A, Fortier M, Gagne F, Gagnon C, Turcotte P, Tayabali A, et al. In vitro immunotoxicology of quantum dots and comparison with dissolved cadmium and tellurium. Environ Toxicol. (2013) 30:9-25. doi: 10.1002/tox.21890

55. Gagne F, Fortier M, Yu L, Osachoff HL, Skirrow RC, van Aggelen G, et al. Immunocompetence and alterations in hepatic gene expression in rainbow trout exposed to CdS/CdTe quantum dots. J Environ Monit. (2010) 12:1556-65. doi: 10.1039/c0em00031k

56. Ahmad F, Liu X, Zhou Y, Yao H. An in vivo evaluation of acute toxicity of cobalt ferrite (CoFe2O4) nanoparticles in larval-embryo Zebrafish (Danio rerio). Aquat Toxicol. (2015) 166:21-8. doi: 10.1016/j.aquatox.2015.07.003.

57. Lovmo SD, Speth MT, Repnik U, Koppang EO, Griffiths GW, Hildahl JP. Translocation of nanoparticles and Mycobacterium marinum across the intestinal epithelium in zebrafish and the role of the mucosal immune system. Dev Comp Immunol. (2017) 67:508-18. doi: 10.1016/j.dci.2016.06.016

58. Felix LC, Ortega VA, Goss GG. Cellular uptake and intracellular localization of poly (acrylic acid) nanoparticles in a rainbow trout (Oncorhynchus mykiss) gill epithelial cell line, RTgill-W1. Aquat Toxicol. (2017) 192:58-68. doi: 10.1016/j.aquatox.2017.09.008

59. Costa L, Mohmood I, Trindade T, Anjum NA, Duarte AC, Pereira E. Phagocytic cell responses to silica-coated dithiocarbamatefunctionalized iron oxide nanoparticles and mercury co-exposures in Anguilla anguilla L. Environ Sci Pollut Res Int. (2016) 23:12272-86. doi: 10.1007/s11356-016-6441-7

60. Christen V, Capelle M, Fent K. Silver nanoparticles induce endoplasmatic reticulum stress response in zebrafish. Toxicol Appl Pharmacol. (2013) 272:519-28. doi: 10.1016/j.taap.2013.06.011

61. Thummabancha K, Onparn N, Srisapoome P. Analysis of hematologic alterations, immune responses and metallothionein gene expression in Nile tilapia (Oreochromis niloticus) exposed to silver nanoparticles. J Immunotoxicol. (2016) 13:909-17. doi: 10.1080/1547691X.2016.1242673

62. Picchietti S, Bernini C, Stocchi V, Taddei AR, Meschini R, Fausto AM, et al. Engineered nanoparticles of titanium dioxide (TIO2): Uptake and biological effects in a sea bass cell line. Fish Shellfish Immunol. (2017) 63:53-67. doi: 10.1016/j.fsi.2017.01.044

63. Jovanovic B, Whitley EM, Kimura K, Crumpton A, Palic D. Titanium dioxide nanoparticles enhance mortality of fish exposed to bacterial pathogens. Environ Pollut. (2015) 203:153-64. doi: 10.1016/j.envpol.2015.04.003

64. Wang Y, Aker WG, Hwang HM, Yedjou CG, Yu H, Tchounwou PB. A study of the mechanism of in vitro cytotoxicity of metal oxide nanoparticles using catfish primary hepatocytes and human HepG2 cells. Sci Total Environ. (2011) 409:475-62. doi: 10.1016/j.scitotenv.2011.07.039

65. Wang T, Chen X, Long X, Liu Z, Yan S. Copper nanoparticles and copper sulphate induced cytotoxicity in hepatocyte primary cultures of Epinephelus coioides. PloS ONE (2016) 11:e0149484. doi: 10.1371/journal.pone.0149484

66. Ganesan S, Anaimalai Thirumurthi N, Raghunath A, Vijayakumar S, Perumal E. Acute and sub-lethal exposure to copper oxide nanoparticles causes oxidative stress and teratogenicity in zebrafish embryos. J Appl Toxicol. (2016) 36:554-67. doi: 10.1002/jat.3224
67. Srikanth K, Pereira E, Duarte AC, Rao JV. Evaluation of cytotoxicity, morphological alterations and oxidative stress in Chinook salmon cells exposed to copper oxide nanoparticles. Protoplasma (2016) 253:873-84. doi: 10.1007/s00709-015-0849-7

68. Ferreira JL, Lonne MN, Franca TA, Maximilla NR, Lugokenski TH, Costa PG, et al. Co-exposure of the organic nanomaterial fullerene $\mathrm{C}(6)(0)$ with benzo[a]pyrene in Danio rerio (zebrafish) hepatocytes: evidence of toxicological interactions. Aquat Toxicol. (2014) 147:76-83. doi: 10.1016/j.aquatox.2013.12.007

69. Farkas J, Christian P, Urrea JA, Roos N, Hassellov M, Tollefsen $\mathrm{KE}$, et al. Effects of silver and gold nanoparticles on rainbow trout (Oncorhynchus mykiss) hepatocytes. Aquat Toxicol. (2010) 96:44-52. doi: 10.1016/j.aquatox.2009.09.016

70. Chen PJ, Tan SW, Wu WL. Stabilization or oxidation of nanoscale zerovalent iron at environmentally relevant exposure changes bioavailability and toxicity in medaka fish. Environ Sci Technol. (2012) 46:8431-9. doi: $10.1021 /$ es 3006783

71. Naha PC, Byrne HJ. Generation of intracellular reactive oxygen species and genotoxicity effect to exposure of nanosized polyamidoamine (PAMAM) dendrimers in PLHC-1 cells in vitro. Aquat Toxicol. (2013) 132-133:61-72. doi: 10.1016/j.aquatox.2013.01.020

72. Wu Y, Zhou Q. Dose- and time-related changes in aerobic metabolism, chorionic disruption, and oxidative stress in embryonic medaka (Oryzias latipes): underlying mechanisms for silver nanoparticle developmental toxicity. Aquat Toxicol. (2012) 124-125:238-46. doi: 10.1016/j.aquatox.2012.08.009

73. Zhao X, Wang S, Wu Y, You H, Lv L. Acute ZnO nanoparticles exposure induces developmental toxicity, oxidative stress and DNA damage in embryo-larval zebrafish. Aquat Toxicol. (2013) 136-137:49-59. doi: 10.1016/j.aquatox.2013.03.019

74. Zhao X, Ren X, Zhu R, Luo Z, Ren B. Zinc oxide nanoparticles induce oxidative DNA damage and ROS-triggered mitochondria-mediated apoptosis in zebrafish embryos. Aquat Toxicol. (2016) 180:56-70. doi: 10.1016/j.aquatox.2016.09.013

75. Ozel RE, Alkasir RS, Ray K, Wallace KN, Andreescu S. Comparative evaluation of intestinal nitric oxide in embryonic zebrafish exposed to metal oxide nanoparticles. Small (2013) 9:4250-61. doi: 10.1002/smll.201301087

76. Srikanth K, Mahajan A, Pereira E, Duarte AC, Venkateswara Rao J. Aluminium oxide nanoparticles induced morphological changes, cytotoxicity and oxidative stress in Chinook salmon (CHSE-214) cells. $J$ Appl Toxicol. (2015) 35:1133-40. doi: 10.1002/jat.3142

77. Wang T, Long X, Liu Z, Cheng Y, Yan S. Effect of copper nanoparticles and copper sulphate on oxidation stress, cell apoptosis and immune responses in the intestines of juvenile Epinephelus coioides. Fish Shellfish Immunol. (2015) 44:674-82. doi: 10.1016/j.fsi.2015.03.030

78. Liu L, Xiao YY, Ji YH, Liu MZ, Chen Y, Zeng YL, et al. CuInS2/ZnS QD exposure induces developmental toxicity, oxidative stress and DNA damage in rare minnow (Gobiocypris rarus) embryos and larvae. Comp Biochem Physiol C Toxicol Pharmacol. (2017) 198:19-27. doi: 10.1016/j.cbpc.2017.04.009

79. Dedeh A, Ciutat A, Treguer-Delapierre M, Bourdineaud JP. Impact of gold nanoparticles on zebrafish exposed to a spiked sediment. Nanotoxicology (2015) 9:71-80. doi: 10.3109/17435390.2014.889238

80. Teles M, Soares A, Tort L, Guimaraes L, Oliveira M. Linking cortisol response with gene expression in fish exposed to gold nanoparticles. Sci Total Environ. (2017) 584-5:1004-1. doi: 10.1016/j.scitotenv.2017.01.153

81. Teles M, Fierro-Castro C, Na-Phatthalung P, Tvarijonaviciute A, Trindade T, Soares AM, et al. Assessment of gold nanoparticle effects in a marine teleost (Sparus aurata) using molecular and biochemical biomarkers. Aquat Toxicol. (2016) 177:125-35. doi: 10.1016/j.aquatox.2016.05.015

82. Rajkumar KS, Kanipandian N, Thirumurugan R. Toxicity assessment on haemotology, biochemical and histopathological alterations of silver nanoparticles-exposed freshwater fish Labeo rohita. Appl Nanosci. (2015) 6:19-29. doi: 10.1007/s13204-015-0417-7

83. Srikanth K, Pereira E, Duarte AC, Ahmad I, Rao JV. Assessment of cytotoxicity and oxidative stress induced by titanium oxide nanoparticles on Chinook salmon cells. Environ Sci Pollut Res Int. (2015) 22:15571-8. doi: $10.1007 / \mathrm{s} 11356-015-4740-\mathrm{z}$ 
84. Chen PJ, Su CH, Tseng CY, Tan SW, Cheng CH. Toxicity assessments of nanoscale zerovalent iron and its oxidation products in medaka (Oryzias latipes) fish. Mar Pollut Bull. (2011) 63:339-46. doi: 10.1016/j.marpolbul.2011.02.045

85. Oberdörster E. Manufactured nanomaterials (Fullerenes, C60) induce oxidative stress in the brain of juvenile Largemouth Bass. Environ Health Perspect. (2004) 112:1058-62. doi: 10.1289/ehp.7021

86. Scown TM, van Aerle R, Johnston BD, Cumberland S, Lead JR, Owen $\mathrm{R}$, et al. High doses of intravenously administered titanium dioxide nanoparticles accumulate in the kidneys of rainbow trout but with no observable impairment of renal function. Toxicol Sci. (2009) 109:372-80. doi: 10.1093/toxsci/kfp064

87. Gagne F, Andre C, Skirrow R, Gelinas M, Auclair J, van Aggelen G, et al. Toxicity of silver nanoparticles to rainbow trout: a toxicogenomic approach. Chemosphere (2012) 89:615-22. doi: 10.1016/j.chemosphere.2012.05.063

88. Federici G, Shaw BJ, Handy RD. Toxicity of titanium dioxide nanoparticles to rainbow trout (Oncorhynchus mykiss): gill injury, oxidative stress, and other physiological effects. Aquat Toxicol. (2007) 84:415-30. doi: 10.1016/j.aquatox.2007.07.009

89. Klaper R, Arndt D, Setyowati K, Chen J, Goetz F. Functionalization impacts the effects of carbon nanotubes on the immune system of rainbow trout, Oncorhynchus mykiss. Aquat Toxicol. (2010) 100:211-7. doi: 10.1016/j.aquatox.2010.07.023.

90. Krishnaraj C, Harper SL, Yun SI. In vivo toxicological assessment of biologically synthesized silver nanoparticles in adult zebrafish (Danio rerio). J Hazard Mater (2016) 301:480-91. doi: 10.1016/j.jhazmat.2015.09.022

91. Torre CD, Buonocore F, Frenzilli G, Corsolini S, Brunelli A, Guidi P, et al. Influence of titanium dioxide nanoparticles on 2,3,7,8-tetrachlorodibenzop-dioxin bioconcentration and toxicity in the marine fish European sea bass (Dicentrarchus labrax). Environ Pollut. (2015) 196:185-93. doi: 10.1016/j.envpol.2014.09.020.

92. Bayat N, Lopes VR, Scholermann J, Jensen LD, Cristobal S. Vascular toxicity of ultra-small $\mathrm{TiO} 2$ nanoparticles and single walled carbon nanotubes in vitro and in vivo. Biomaterials (2015) 63:1-13. doi: 10.1016/j.biomaterials.2015.05.044

93. Chupani L, Zuskova E, Niksirat H, Panacek A, Lunsmann V, Haange SB, et al. Effects of chronic dietary exposure of zinc oxide nanoparticles on the serum protein profile of juvenile common carp (Cyprinus carpio L.). Sci Total Environ (2017) 579:1504-11. doi: 10.1016/j.scitotenv.2016.11.154

94. Thit A, Skjolding LM, Selck H, Sturve J. Effects of copper oxide nanoparticles and copper ions to zebrafish (Danio rerio) cells, embryos and fry. Toxicol in vitro (2017) 45(Pt 1):89-100. doi: 10.1016/j.tiv.2017.08.010

95. Jovanovic B, Ji T, Palic D. Gene expression of zebrafish embryos exposed to titanium dioxide nanoparticles and hydroxylated fullerenes. Ecotoxicol Environ Saf. (2011) 74:1518-25. doi: 10.1016/j.ecoenv.2011.04.012.

96. Truong L, Tilton SC, Zaikova T, Richman E, Waters KM, Hutchison JE, et al. Surface functionalities of gold nanoparticles impact embryonic gene expression responses. Nanotoxicology (2013) 7:192-201. doi: 10.3109/17435390.2011.648225

97. Oliveira E, Casado M, Faria M, Soares AM, Navas JM, Barata C, et al. Transcriptomic response of zebrafish embryos to polyaminoamine (PAMAM) dendrimers. Nanotoxicology (2014) 8 (Suppl. 1):92-9. doi: $10.3109 / 17435390.2013 .858376$

98. Myrzakhanova M, Gambardella C, Falugi C, Gatti AM, Tagliafierro G, Ramoino P, et al. Effects of nanosilver exposure on cholinesterase activities, CD41, and CDF/LIF-like expression in zebrafish (Danio rerio) larvae. Biomed Res Int. (2013) 2013:205183. doi: 10.1155/2013/205183

99. Kim RO, Choi JS, Kim BC, Kim WK. Comparative analysis of transcriptional profile changes in larval zebrafish exposed to zinc oxide nanoparticles and zinc sulfate. Bull Environ Contam Toxicol. (2017) 98:1839. doi: 10.1007/s00128-016-1995-0

100. Karthikeyeni S, Vijayakumar S, Vasanth S, Ganesh A, Manimegalai M, Subramanian P. Biosynthesis of Iron oxide nanoparticles and its haematological effects on fresh water fish Oreochromis mossambicus. J Acad Indus Res. (2013) 1:645-9.

101. Yue Y, Li X, Sigg L, Suter MJ, Pillai S, Behra R, et al. Interaction of silver nanoparticles with algae and fish cells: a side by side comparison. $J$ Nanobiotechnol. (2017) 15:16. doi: 10.1186/s12951-017-0254-9
102. Smith PA, Contreas JR, Larenas JJ, Aguillon JC, Garces LH, Perez B, et al. Immunization with bacterial antogens: piscirickettsiosis. Dev Biol Standard. (1997) 90:161-6.

103. Girilal M, Krishnakumar V, Poornima P, Mohammed Fayaz A, Kalaichelvan PT. A comparative study on biologically and chemically synthesized silver nanoparticles induced Heat Shock Proteins on fresh water fish Oreochromis niloticus. Chemosphere (2015) 139:461-8. doi: 10.1016/j.chemosphere.2015.08.005

104. Li S, Pan X, Wallis LK, Fan Z, Chen Z, Diamond SA. Comparison of $\mathrm{TiO} 2$ nanoparticle and graphene-TiO2 nanoparticle composite phototoxicity to Daphnia magna and Oryzias latipes. Chemosphere (2014) 112:62-9. doi: 10.1016/j.chemosphere.2014.03.058

105. Pham CH, Yi J, Gu MB. Biomarker gene response in male Medaka (Oryzias latipes) chronically exposed to silver nanoparticle. Ecotoxicol Environ Saf. (2012) 78:239-45. doi: 10.1016/j.ecoenv.2011.11.034

106. Fernandez-Cruz ML, Lammel T, Connolly M, Conde E, Barrado AI, Derick S, et al. Comparative cytotoxicity induced by bulk and nanoparticulated $\mathrm{ZnO}$ in the fish and human hepatoma cell lines PLHC-1 and Hep G2. Nanotoxicology (2013) 7:935-52. doi: 10.3109/17435390.2012.676098

107. Farkas J, Salaberria I, Styrishave B, Stankova R, Ciesielski TM, Olsen AJ, et al. Exposure of juvenile turbot (Scophthalmus maximus) to silver nanoparticles and 17alpha-ethinylestradiol mixtures: Implications for contaminant uptake and plasma steroid hormone levels. Environ Pollut. (2017) 220(Pt A):328-36. doi: 10.1016/j.envpol.2016.09.067

108. Van Gestel CA, Van Brummelen T. Incorporation of the biomarker concept in ecotoxicology calls for a redificition of terms. Ecotoxicology (1996) 5:21725. doi: 10.1007/BF00118992

109. Slaninova A, Smutna M, Modra H, Svobodova Z. A review: oxidative stress in fish induced by pesticides. Neuro Endocrinol Lett. (2009) 30:2-12.

110. Rehberger K, Werner I, Hitzfeld B, Segner H, Baumann L. 20 Years of fish immunotoxicology - what we know and where we are. Crit Rev Toxicol. (2017) 47:509-35. doi: 10.1080/10408444.2017.1288024

111. Lushchak VI. Contaminant-induced oxidative stress in fish: a mechanistic approach. Fish Physiol Biochem. (2016) 42:711-47. doi: 10.1007/s10695-015-0171-5

112. Ai-Jun M, Zhi-Hui H, Xin-An W. Changes in protein composition of epidermal mucus in turbot Scophthalmus maximus (L.) under high water temperature. Fish Physiol Biochem. (2013) 39:1411-8. doi: 10.1007/s10695-013-9795-5

113. Cordero H, Morcillo P, Cuesta A, Brinchmann MF, Esteban MA. Differential proteome profile of skin mucus of gilthead seabream (Sparus aurata) after probiotic intake and/or overcrowding stress. J Proteom. (2016) 132:41-50. doi: 10.1016/j.jprot.2015.11.017.

114. Shephart K. Functions for fish mucus. Rev Fish Biol Fish (1994) 4:401-29. doi: $10.1007 / \mathrm{BF} 00042888$

115. Campos-Perez J, Ward M, Grabowski P, Ellis AE, Secombes C. The gills are an important site of iNOS expression in rainbow trout Oncorhynchus mykiss after challenge with the Gram-positive. Immunology (2000) 99:15361. doi: 10.1046/j.1365-2567.2000.00914.x

116. Ebran N, Julien S, Orange N, Saglio P, Lemaitre C, Molle G. Pore-forming properties and antibacterial activity of proteins extracted from epidermal mucus of fish. Compar Biochem Physiology Part A Mol Integr Physiol. (1999) 122:181-9. doi: 10.1016/S1095-6433(98)10165-4

117. Bols NC, Brubacher J, Ganassin R, Lee L. Ecotoxicology and innate immunity in fish. Dev Compar Immunol. (2001) 25:853-73. doi: 10.1016/S0145-305X(01)00040-4

118. Brinchmann M. Immune relevant molecules identified in the skin mucus of fish using -omics technologies. Mol Biosyst. (2016) 12:2056-63. doi: $10.1039 / \mathrm{c} 5 \mathrm{mb} 00890 \mathrm{e}$

119. Fast M, Sims D, Burka JF, mustafa A, Ross N. Skin morphology and humoral non-specific defence parameters of mucus and plasma in rainbow trout, coho and Atlantic salmon. Comp Biochem Physiol, Part A Mol Integr Physiol. (2002) 132:645-57. doi: 10.1016/S1095-6433(02) 00109-5

120. Hwang P, Lee TH, Lin L. Effects of short-term exposure to sublethal concentrations of silver nanoparticles on histopathology and electron microscope ultrastructure of zebrafish (Danio rerio) gills. Am J Physiol Regul Integr Comp Physiol. (2011) 301:28-47. 
121. Wood CM. Chapter 9. In: Wood CM FA, Brauner CJ, editor Homeostasis and Toxicology of Non-Essential Metals, Fish Physiology. Oxford, UK: Academic Press/Elsevier (2011). p. 429-484.

122. Wolf JC, Baumgartner WA, Blazer VS, Camus AC, Engelhardt JA, Fournie JW, et al. Nonlesions, misdiagnoses, missed diagnoses, and other interpretive challenges in fish histopathology studies: a guide for investigators, authors, reviewers, and readers. Toxicol Pathol. (2015) 43:297325. doi: 10.1177/0192623314540229.

123. Mansouri B, Johari S. Effects of short-term exposure to sublethal concentrations of silver nanoparticles on histopathology and electron microscope ultrastructure of Zebrafish (Danio rerio) gills. Iran J Toxicol. (2016) 10:15-20.

124. Handy RD, Henry TB, Scown TM, Johnston BD, Tyler CR. Manufactured nanoparticles: their uptake and effects on fish: a mechanistic analysis. Ecotoxicology (2008) 17:396-409. doi: 10.1007/s10646-008-0205-1

125. Gustafson HH, Holt-Casper D, Grainger DW, Ghandehari H. Nanoparticle uptake: the phagocyte problem. Nano Today (2015) 10:487-510. doi: 10. 1016/j.nantod.2015.06.0065

126. Hodgkinson JW, Grayfer L, Belosevic M. Biology of bony fish macrophages. Biology (2015) 4:881-906. doi: 10.3390/biology4040881

127. Bianchi ME, Manfredi AA. How macrophages ring the inflammation alarm. Proc Natl Acad Sci USA. (2014) 111:2866-7. doi: 10.1073/pnas.1324285111

128. Zelikoff JT. Biomarkers of immunotoxicity in fish and other nonmammalian sentinel species: predictive value for mammals? Toxicology (1998) 129:63-71.

129. Steinel NC, Bolnick DI. Melanomacrophage Centers As a Histological Indicator of Immune Function in Fish and Other Poikilotherms. Frontiers in immunology (2017) 8:827. doi: 10.3389/fimmu.2017.00827

130. Capkin E, Ozcelep T, Kayis S, Altinok I. Antimicrobial agents, triclosan, chloroxylenol, methylisothiazolinone and borax, used in cleaning had genotoxic and histopathologic effects on rainbow trout. Chemosphere (2017) 182:720-9. doi: 10.1016/j.chemosphere.2017.05.093.PubMed PMID:28531838

131. Haaparanta A, Valtonen T, Hoffmann R, Holmes J. Do macrophage centres in freshwater fishes refelect the differences in water quality? Aquat Toxicol. (1996) 34:253-72.

132. Fu D, Bridle A, Leef M, Gagnon MM, Hassell KL, Nowak BF. Using a multi-biomarker approach to assess the effects of pollution on sand flathead (Platycephalus bassensis) from Port Phillip Bay, Victoria, Australia. Mar Poll Bullet. (2017) 119:211-9. doi: 10.1016/j.marpolbul.2017.03.067

133. Havixbeck JJ, Rieger AM, Wong ME, Hodgkinson JW, Barreda DR. Neutrophil contributions to the induction and regulation of the acute inflammatory response in teleost fish. J Leukocyte Biol. (2016) 99:241-52. doi: 10.1189/jlb.3HI0215-064R

134. Jenne CN, Liao S, Singh B. Neutrophils: multitasking first responders of immunity and tissue homeostasis. Cell Tissue Res. (2018) 371:395-7. doi: 10.1007/s00441-018-2802-5

135. Lin MH, Lin CF, Yang SC, Hung CF, Fang JY. The Interplay Between Nanoparticles and Neutrophils. J Biomed Nanotechnol. (2018) 14:66-85. doi: 10.1166/jbn.2018.2459

136. Jaeschke H, Gores G, Cederbaum A, Hinson J, Pessayre D, Lemasters J. Mechanisms of hepatotoxicity. Toxicol Sci. (2002) 65:166-76.

137. Goncalves DM, de Liz R, Girard D. Activation of neutrophils by nanoparticles. Sci World J. (2011) 11:1877-85. doi: 10.1100/2011/ 768350

138. Parra D, Takizawa F, Sunyer JO. Evolution of B cell immunity. Annu Rev Anim Biosci. (2013) 1:65-7. doi: 10.1146/annurev-animal-031412-103651

139. Hernández P, Strzelecka P, Athanasiadis E, Hall D, Robalo A, Collins C, et al. Single cell transcriptional analysis reveals ILC like cells in zebrafish. Sci Immunol. (2018) 3:eaau5265. doi: 10.1126/sciimmunol.aau5265

140. Eberl G, Colonna M, Di Santo JP, McKenzie AN. Innate lymphoid cells. Innate lymphoid cells: a new paradigm in immunology. Science (2015) 348:aaa6566. doi: 10.1126/science.aaa6566

141. Ignacio A, Naffah C, Olsen N, Camara S. Innate lymphoid cells in tissue homeostasis and diseases. World J Hepatol. (2017) 9:979-89. doi: 10.4254/wjh.v9.i23.979

142. Verma A, Stellacci F. Effect of surface properties on nanoparticle-cell interactions. Small (2010) 6:12-21. doi: 10.1002/smll.200901158
143. Canton I, Battaglia G. Endocytosis at the nanoscale. Chem Soc Rev. (2012) 41:2718-39. doi: 10.1039/c2cs15309b

144. Van Furth R. Mononuclear Phagocytes. Biology of Monocytes and Macrophages. Dordrecht: Springer Science+Business Media (1992).

145. Shukla RK, Sharma V, Pandey AK, Singh S, Sultana S, Dhawan A. ROS-mediated genotoxicity induced by titanium dioxide nanoparticles in human epidermal cells. Toxicol In Vitro (2011) 25:231-41. doi: 10.1016/j.tiv.2010.11.008

146. Patri A, Umbreit T, Zheng J, Nagashima K, Goering P, Francke-Carroll $\mathrm{S}$, et al. Energy dispersive $\mathrm{X}$-ray analysis of titanium dioxide nanoparticle distribution after intravenous and subcutaneous injection in mice. J Appl Toxicol. (2009) 29:662-72. doi: 10.1002/jat.1454.PubMed PMID:19626582

147. Betteridge J. What is oxidative stress? Metabolism (2000) 49:3-8. doi: 10.1016/S0026-0495(00)80077-3

148. Valavanidis A, Vlahogianni T, Dassenakis M, Scoullos M. Molecular biomarkers of oxidative stress in aquatic organisms in relation to toxic environmental pollutants. Ecotoxicol Environ Saf. (2006) 64:178-89. doi: 10.1016/j.ecoenv.2005.03.013

149. D’Autreaux B, Toledano MB. ROS as signalling molecules: mechanisms that generate specificity in ROS homeostasis. Nat Rev Mol Cell Biol. (2007) 8:813-24. doi: $10.1038 / \mathrm{nrm} 2256$

150. Lugrin J, Rosenblatt-Velin N, Parapanov R, Liaudet L. The role of oxidative stress during inflammatory processes. Biol Chem. (2014) 395:203-30. doi: 10.1515/hsz-2013-0241

151. Bogdan C. Nitric oxide synthase in innate and adaptive immunity: an update. Trends Immunol. (2015) 36:161-78. doi: 10.1016/j.it.2015. 01.003

152. Eddy FB. Role of nitric oxide in larval and juvenile fish. Compar Biochem Physiol Part A (2005) 142:221-30. doi: 10.1016/j.cbpb.2005. 05.038

153. Neumann N, Belosevic M. Deactivation of primed respiratory burst response of goldfish macrophages by leukocytes-derived macrophage activating factors. Dev Comp Immunol. (1996) 20:427-39. doi: 10.1016/S0145-305X(96)00029-8

154. He L, He T, Farrar S, Ji L, Liu T, Ma X. Antioxidants maintain cellular redox homeostasis by elimination of reactive oxygen species. Cell Physiol Biochem. (2017) 44:532-53. doi: 10.1159/000485089

155. Devi GP, Ahmed KB, Varsha MK, Shrijha BS, Lal KK, Anbazhagan V, et al. Sulfidation of silver nanoparticle reduces its toxicity in zebrafish. Aquat Toxicol. (2015) 158:149-56. doi: 10.1016/j.aquatox.2014.11.007

156. Yu B. Cellular defenses against damage from reactive oxygen species. Physiol Rev. (1994) 74:139-62. doi: 10.1152/physrev.1994.74.1.139

157. Birden E, Sahiner U, Sackesen C, Erzurum S, O K. Oxidative stress and antioxidant defense. WAO J. (2012) 5:9-19. doi: 10.1097/WOX.0b013e3182439613

158. Franchina DG, Dostert C, Brenner D. Reactive oxygen species: involvement in T cell signaling and metabolism. Trends Immunol. (2018) 39:489-502. doi: 10.1016/j.it.2018.01.005

159. Di Giulio R, Meyer J. Reactive Oxygen Species and Oxidative Stress. In: Di Giulio R, Hinton J, editors. The Toxicology of Fishes. Boca Raton, FL: CRC Press, Taylor and Francis Group (2008). p. 273-326.

160. Secombes C, Hardie L, Daniels G. Cytokines in fish: an update. Fish Shellfish Immunol. (1996) 6:291-304.

161. Zou J, Secombes CJ. Teleost fish interferons and their role in immunity. Dev Comp Immunol. (2011) 35:1376-87. doi: 10.1016/j.dci.2011. 07.001

162. Wang T, Secombes CJ. The cytokine networks of adaptive immunity in fish. Fish Shellfish Immunol. (2013) 35:1703-18. doi: 10.1016/j.fsi.2013. 08.030

163. Qi Z, Holland JW, Jiang Y, Secombes CJ, Nie P, Wang T. Molecular characterization and expression analysis of four fish-specific CC chemokine receptors CCR4La, CCR4Lc1, CCR4Lc2 and CCR11 in rainbow trout (Oncorhynchus mykiss). Fish Shellfish Immunol. (2017) 68:411-27. doi: 10.1016/j.fsi.2017.07.031

164. Secombes CJ. What's new in fish cytokine research? Fish Shellfish Immunol. (2016) 53:1-3. doi: 10.1016/j.fsi.2016.03.035

165. Magnadottir B. Innate immunity of fish (overview). Fish Shellfish Immunol. (2006) 20:137-51. doi: 10.1016/j.fsi.2004.09.006 
166. Magnadottir B, Lange S, Gudmundsdottir S, Bogwald J, Dalmo RA. Ontogeny of humoral immune parameters in fish. Fish Shellfish Immunol. (2005) 19:429-39. doi: 10.1016/j.fsi.2005.03.010

167. Saurabh S, Sahoo PK. Lysozyme: an important defence molecule of fish innate immune system. Aquacul Res. (2008) 39:223-39. doi: 10.1111/j.1365-2109.2007.01883.x

168. Buonocore F, Randelli E, Trisolino P, Facchiano A, de Pascale D, Scapigliati G. Molecular characterization, gene structure and antibacterial activity of a g-type lysozyme from the European sea bass (Dicentrarchus labrax L.). Mol Immunol. (2014) 62:10-8. doi: 10.1016/j.molimm.2014.05.009

169. Whyte SK. The innate immune response of finfish a review of current knowledge. Fish Shellfish Immunol. (2007) 23:1127-51. doi: 10.1016/j.fsi.2007.06.005

170. Chakraborti S, Chatterjee T, Joshi P, Poddar A, Bhattacharyya B, Singh SP, et al. Structure and activity of lysozyme on binding to $\mathrm{ZnO}$ nanoparticles. Langmuir (2010) 26:3506-13. doi: 10.1021/la903118c

171. Vertegel A, Siegel AM, R.R. C, Dordick J. Silica nanoparticle size influences the structure and enzymatic activity of adsorbed lysozyme. Langmuir (2004) 20:6800-7. doi: 10.1021/la0497200

172. Linnenbrink M. Nanotechnology \& Nanomaterials Research. U.S. Environmental Protection Agency. Washington, DC: Office of Research and Development.

173. Vance ME, Kuiken T, Vejerano EP, McGinnis SP, Hochella MF Jr, Rejeski $\mathrm{D}$, et al. Nanotechnology in the real world: Redeveloping the nanomaterial consumer products inventory. Beilstein J Nanotechnol. (2015) 6:1769-80. doi: $10.3762 /$ bjnano.6.181
174. Services DoHaH. Ocupational Exposure to Carbon Nanotubes and Nanofibers. Centers for Disease Control and Prevention. Cincinnati, $\mathrm{OH}$ : National Institute for Occupational Safety and Health (2013).

175. Division UEPAOoRaDNERLES. Sampling and Analysis of Nanomaterials in the Environment: A State-of-the-Science Review. EPA. Washington, DC: United States Environmental Protection Agency (2008).

176. Simonet BM, Valcarcel M. Monitoring nanoparticles in the environment. Anal Bioanal Chem. (2009) 393:17-21. doi: 10.1007/s00216-0082484-z

177. Reitsema T, Nice H, Leusch F, Quayle P, Chapman H, Khan S, et al. Development of an "Ecotoxicity Toolbox" to Characterise Water Quality for Recycling. Perth, WA: Goverment of Western Australia; Departament of Water (2010).

Conflict of Interest Statement: The authors declare that the research was conducted in the absence of any commercial or financial relationships that could be construed as a potential conflict of interest.

Copyright (c) 2019 Torrealba, More-Bayona, Wakaruk and Barreda. This is an openaccess article distributed under the terms of the Creative Commons Attribution License (CC BY). The use, distribution or reproduction in other forums is permitted, provided the original author(s) and the copyright owner(s) are credited and that the original publication in this journal is cited, in accordance with accepted academic practice. No use, distribution or reproduction is permitted which does not comply with these terms. 